TOMASZ KEYS

Katedra Filmu i Mediów Audiowizualnych Uniwersytet Łódzki

\title{
Abel Gance po trzykroć oskarża: metafizyka i apokaliptyczna wyobraźnia w służbie pacyfizmu
}

\begin{abstract}
Kłys Tomasz, Abel Gance po trzykroć oskarża: metafizyka i apokaliptyczna wyobraźnia $w$ służbie pacyfizmu [Abel Gance accuses thrice: metaphysics and apocalyptic imagery in the service of pacifism]. "Images" vol. XXX, no. 39. Poznań 2021. Adam Mickiewicz University Press. Pp. 67-94. ISSN 1731-450X. DOI 10.14746/i.2021.39.04.
\end{abstract}

This text is inspired by monumental and editorially perfect BluRay/DVD box set J'accuse (Gaumont, Paris 2017). It includes BluRay and DVD editions of all three J'accuse films $(1919,1937,1956)$, two of Gance's other films, specifying the context of the "trilogy" (Les Gaz mortels, 1916 and La Fin du monde, 1931) and the director's large monography by Laurent Véray. From this revelatory archive emerges the image of Abel Gance as an artist who for 40 years of his filmmaking career was incessantly reworking the deep trauma caused by World War One. It resulted in three J'accuse films, two other finished films and some other never realized screenplays and projects which made up particular work-in-progress whose mission is a message of peace. The text analyzes all three versions of J'accuse, concentrating on their allegorical style, the metaphysical concept of the resurrection of fallen soldiers and the apocalyptic vision of resurrected dead men's processions, which in its horror should persuade mankind to stop all wars. In the last J'accuse (1956) - in fact, a strongly shortened and reedited film from 1937 - Gance used the technique of the triptych, in which the picture was projected by three projectors set in parallel on the large screen with 4:1 proportions. This version, immersing the spectator perceptually and sensorily in the wide-format picture full of war horrors, seems today to be a much more effective medium for the message of peace than indecisive between pacifism and patriotism, the impressionistic in style film from 1919, or the laden with pathos verbal rhetoric of J'accuse 1937.

KeYwords: J'accuse, Abel Gance, World War One, pacifism, war trauma, resurrection, Magirama

Gdy przed kilkunastu laty poznałem wydane w roku 2008 przez amerykańską firmę Flicker Alley płytowe edycje filmów Abla Gance’a, Oskarżam (J’accuse, 1919) i Koło udręki (La Roue, 1923) - tego drugiego filmu jeszcze w niepełnej wersji, zawierającej tylko $20 \mathrm{z} 32$ rolek oryginału, czyli 4,5 godziny projekcji z pierwotnych siedmiu - to nie miałem wątpliwości, iż muszę skorygować prowadzony przez siebie kurs historii filmu. Te dwa niewątpliwe arcydzieła objawiały, iż po pierwsze, z czterech filarów francuskiego impresjonizmu filmowego (Gance, L'Herbier, Delluc, Epstein) Gance to filar najważniejszy i najpotężniejszy estetycznie, po drugie - że bez inspiracji nimi nie byłoby ani Zmęczonej Śmierci Fritza Langa czy Furmana śmierci Victora Sjöströma, ani górskich filmów Arnolda Fancka czy Bestii ludzkiej Jeana Renoira, nie mówiąc już o sowieckiej szkole montażu, która, naśladując zuchwałe rozwiązania montażowe Gance'a, nie osiągnęła nigdy tej pełni estetycznego i technicznego zuchwalstwa, jaką zaprezentował francuski twórca. Kolejne trzy edycje z ostatnich lat to przekonanie o wielkości

\section{Images}

vol. XXX/no. 39

Poznań 2021

ISSN 1731-45OX 
Gance’a mogły tylko utwierdzić: BFI w roku 2016 wydał Napoleona (1927), Gaumont w 2017 - olbrzymi i elegancki box pt. J'accuse, zawierający nie tylko trzy różne, a tak zatytułowane filmy z lat 1919, 1937 i 1956, ale i faksymile scenariuszy pierwszych dwóch, obszerną książkową monografię Gance’a autorstwa Laurenta Véray, oraz dopełniające rozpisany na dziesięciolecia projekt J'accuse inne pełnometrażowe filmy fabularne Gance'a: Śmiercionośne gazy (Les Gaz mortels, 1916) i Koniec świata (La Fin du monde, 1931); wreszcie w styczniu 2021 Pathé (spadkobierca pierwotnego producenta filmu) wypuścił odrestaurowaną pełną siedmiogodzinną wersję Koła udręki. Wszystkie te edycje na olśniewających jakością obrazu kopiach Blu-ray demonstrują plastyczną urodę alegorycznych kompozycji w kadrach Gance'a, fotogenię licznych w tych filmach naturalnych pejzaży i portretowych zbliżeń twarzy, techniczną perfekcję podwójnych ekspozycji (zwłaszcza we wszystkich wersjach J'accuse), zuchwalstwo montażu ujęć podprogowych dla kreacji suspensu bądź Joycéowskiego strumienia świadomości (Koło udręki, Koniec świata), porywające, apokaliptyczne sceny masowe (we wszystkich filmach), wyzywającą percepcyjnie widza technikę poliwizji z podzielonym na wiele pól ekranem (wyprzedzającą o pół wieku rozwiązania Zbigniewa Rybczyńskiego z filmu Nowa książka), antycypującą formaty filmu szerokoekranowego technikę tryptyku z trzema równoległymi ekranami, które mogły tworzyć jeden superpanoramiczny obraz, albo sugerować tryptyk z ołtarzem i bocznymi skrzydłami, albo pokazywać trzy różne obrazy, co niezależnie od wyboru było równie percepcyjnie wymagające co poliwizja (Napoleon, J'accuse 1956). W kontekście tych edycji nie ma wątpliwości - Abel Gance jest jednych z największych technicznych i estetycznych innowatorów w historii filmu, artystą-wizjonerem, wielkim nawet w swych artystycznych porażkach[1].

Choć $\mathrm{z}$ racji choćby swych rozmiarów (7 i 6 godzin projekcji), wielości nowatorskich rozwiązań i wpływu na kino światowe, to Koło udręki i Napoleon jawią się jako jego dwa główne opera magna, ja chciałem w niniejszym tekście zająć się serią trzech filmów zatytułowanych J’accuse czyli Oskarżam. Gdy traktować je jako trzy różne dzieła, tylko pierwsze z nich, z roku 1919, do dziś wydaje się wielkim osiągnięciem artystycznym; było zresztą wielkim sukcesem frekwencyjnym i zyskało aplauz krytyki w swej epoce. Na nim też skupię przede wszystkim swą uwagę. Pozostałe dwa, choć dziś budzą raczej mieszane uczucia, stanowią jednak dla pierwszego niezbędny kontekst, tworząc w twórczości Gance'a swoisty tryptyk, a w kontekście wiedzy pozatekstowej oraz w towarzystwie innych filmów (jak wzmiankowane już Śmiercionośne gazy czy Koniec świata) jawią się jako swego rodzaju work-in-progress, nieustanne przepracowywanie traumy spowodowanej I wojną światową

[1] Tę przez dziesięciolecia niezauważoną czy zapomnianą wielkość artystyczną Gance’a od razu dostrzegł Karol Irzykowski, który filmom francuskiego mistrza poświęcił wnikliwe passusy swego teoretycznofilmowego opus magnum i swych recenzji. Zob. K. Irzykowski, Dziesiąta Muza oraz pomniejsze pisma filmowe, Kraków 1982, s. 99-102, 116-118, 278-280, 410-414. 
i jej skutkami, traumy, która wielkiego artystę zmusiła do przyjmowania roli wizjonera, proroka, kaznodziei - nawet za cenę pewnej retoryczności i dosłowności, niekoniecznie służącej poziomowi artystycznemu dzieł. Gance jednak nie uchylił się od tej roli i realizował ją - z przerwami - na przestrzeni ponad 40 lat[2].

Poważne schorzenia (zmiany gruźlicze w płucach, permanentne zapalenie krtani i hipoalbuminemia) sprawiły, że Gance nie trafił na front I wojny światowej. Zgłosił się za to do Section Cinématographique armii francuskiej (SCA), skąd jednak szybko wyciągnął go Charles Pathé, który wolał nie tracić świetnie zapowiadającego się zakontraktowanego reżysera. Gance miał bowiem „na cały okres wojny” kontrakt ze spółką Film d’Art, której Pathé był jednym z założycieli i głównych udziałowców. To właśnie dla niej Gance wyreżyserował kilka filmów, wśród których tematykę bieżącej wojny podejmowały Kwiat ruin (La Fleur des ruines, 1915) i Bohaterstwo Paddy (L'Heroisme de Paddy, 1915) [3]. Dramat żołnierzy zaatakowanych 22 kwietnia 1915 roku gazem bojowym pod Ypres niewątpliwie wpłynął na fabularny koncept kolejnego, choć nie bezpośrednio wojennego filmu Gance’a, Śmiercionośne gazy (1916). W tym współczesnym filmie sensacyjnym, z akcją w Meksyku i we Francji, pełnym rozmaitych śmiercionośnych substancji, od jadów węży po produkowane przemysłowo gazy bojowe, wskutek akcji terrorystycznej toksyczny obłok zabija robotników w fabryce i wkrótce zagraża pobliskiemu miastu. Natomiast powstała w roku 1917 Strefa śmierci (La Zone de la mort), w której gigantyczne spustoszenie sieje radioaktywny meteoryt, była niewątpliwie z jej apokaliptycznymi obrazami metaforą zniszczeń wojennych, a wobec realizowanego rok później Oskarżam pełniła funkcje podobne do tych, jakie będzie miał wobec drugiej wersji J’accuse film Koniec świata z 1931 roku: preludium, wstępnego szkicu i stylistycznego poligonu.

Gance jednak w tym wczesnym etapie swego rozwoju artystycznego, który rozpoczął się jeszcze w belle époque, a krystalizował w latach wojny, nie tylko reżyserował filmy, ale i pisał scenariusze. Nie doczekały się wprawdzie realizacji, ale podobnie jak planowany pod koniec wojny cykl filmowy (również nigdy nieurzeczywistniony) dają one pojęcie o przyjętej przez reżysera jeszcze przed wybuchem wojny roli „proroka pokoju”. Świadczy o nim choćby scenariusz z roku 1911, z akcją osadzoną w odległej jeszcze wówczas przyszłości, bo w roku 2000, zatytułowany Ostatnie pole bitwy albo spisek flag (Le Dernier champ de bataille ou la

[2] Niniejszy wywód jest rezultatem zarówno mojego analitycznego oglądania wszystkich filmów zawartych w boksie J'accuse (Gaumont, Paris 2017), tj. trzech wersji J'accuse (1919, 1937, 1956), filmów Gance’a Śmiercionośne gazy (1916) i Koniec świata (1931) oraz filmu Mères françaises (1916) Louisa Mercantona i René Hervila umieszczonego w nim w materiałach dodatkowych, jak i lektury książki Laurenta Véray Abel Gance: Le Visionnaire contrarié
/ Abel Gance: The Thwarted Visionary, opublikowanej w dwujęzycznej francuskiej i angielskiej wersji wyłącznie dla tego wydania. Jest to rzetelnie udokumentowana, obszerna (około 120 stron w każdym z języków, ale za to w formacie $\mathrm{A}_{4}$ i w podwójnych kolumnach), monografia zarówno samego Gance’a, jak i jego work-in-progress, czyli trzech wersji J'accuse i ich kontekstów.

[3] L. Véray, op.cit., s. 14. 


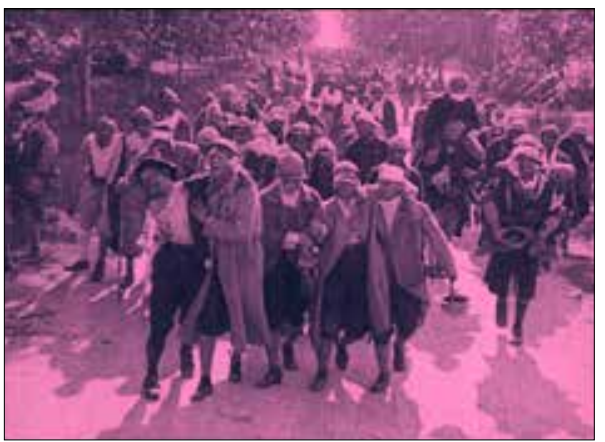

Il. 1. Kadr z filmu Oskarżam (1919). Pochód zmartwychwstańców - pierwszy z lewej, bez prawej ręki, pisarz Blaise Cendrars, przyjaciel Gance’a

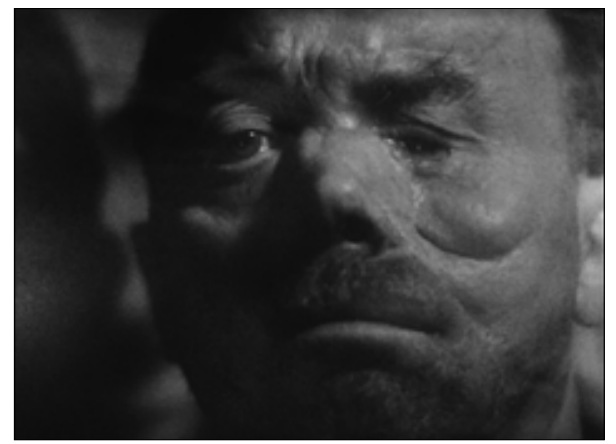

Il. 2. Kadr z filmu Oskarzam (1937). Człowiek bez twarzy ze stowarzyszenia płk. Picota conspiration des drapeaux). „Wrogie wojska tej wyobrażonej wojny uświadamiają sobie absurd walki, gdy budzą się w swych obozach, odkrywszy, iż ich flagi narodowe stały się białe i zjednoczyły się nocą, by narzucić pokój. W wielce alegorycznej scenie końcowej żołnierze padają na kolana, a czerwone od krwi pole bitwy rozjaśnia się i przekształca w rozległy, oświetlony słońcem łan zboża” [4]. Tekst scenariusza dookreśla szczegóły: „Żołnierze ściskają sobie dłonie, obejmują się, znikają mundury, karabiny zostają zastąpione przez kosy, i wszyscy, bratersko zjednoczeni, spieszą na żniwa... nie ma już więcej ostatniego pola bitwy..."[5]. Gance’a napawała także niepokojem możliwość zastosowania na szkodę ludzkości osiągnięć nauki i wynalazków technicznych. Scenariusz zatytułowany L’Aéro-infernal z roku 1914 przedstawiał fabułę zogniskowaną wokół wynalazku śmiercionośnego samolotu o niespotykanych wówczas możliwościach rażenia, który wskutek dywersji mógł trafić w ręce „wroga”[6]. W Widmie okopów (Le Spectre de tranchées), scenariuszu z roku 1915, uczony pracuje nad "zbroją" z hartowanego szkła, mającą zapewnić bezpieczeństwo walczącym na froncie. Dywersja „wroga” powoduje jednak wdrożenie do produkcji wadliwego prototypu, wskutek czego żołnierze nie tylko nie są chronieni, ale masowo wręcz giną[7]. Temat ochrony ciała przez odporną na wszelkie pociski i razy zbroję chyba zresztą szczególnie Gance’a frapował, bo pracuje nad podobnym projektem (zresztą także bezskutecznie) również Jean Diaz, bohater drugiego Oskarżam (1937). Tę idée fixe można chyba tłumaczyć traumą, jakiej doznał, zobaczywszy już w początkach wojny straszliwe niekiedy obrażenia, jakich doznali ranni na froncie[8]. Stąd też w pierwszym Oskarżam na czele pochodu zmartwychwstałych poległych znajdzie się jego jednoręki wskutek ran wojennych przyjaciel, pisarz Blaise Cendrars [9], zaś podobny pochód z drugiej wersji otwierać będą les hommes sans visage, prawdziwi weterani $\mathrm{z}$ potwornie zdeformowanymi przez wojenne okaleczenia twarzami, zrzeszeni w stowarzyszeniu „ludzi bez twarzy”, którego prezesem był pułkownik Picot[10].

Ich widok miał budzić przerażenie (i przerażał, zarówno wewnątrzdiegetycznych świadków pochodu, jak i widzów filmu), przez co
[4] L. Véray, op.cit., s. 17.

[5] Tekst scenariusza Gance’a cytuję za: L. Véray, op.cit., s. 17.

[6] L. Véray, op.cit., s. 17.

[7] Ibidem, s. 18.

[8] Ibidem, s. 43.

[9] Na temat utraty przez Cendrarsa na froncie prawej ręki, a także wskazówek, jakich udzielał Gance’owi podczas realizacji scen batalistycznych, zob. L. Véray, op.cit., s. 37. Na s. 46 tej książki znajduje się kadr z Oskarżam (1919), w którym na czele pochodu zmartwychwstałych żołnierzy widzimy Cendrarsa z zakrwawionym kikutem ręki; prowadzi go François Laurin, jeden $z$ dwójki głównych bohaterów filmu, grany przez Séverina-Marsa.

[10] Zob. L. Véray, op.cit., s. 87. 
zarazem wzbudzał zgrozę, wynikłą z uświadomienia sobie i unaocznienia konsekwencji wojny dla jednostki, dla konkretnych ludzi tak potwornie przez wojnę okaleczonych[11]. Niewątpliwie pacyfistyczna i humanistyczna intencja, stojąca za tym szokującym pomysłem, spowodowała, iż weterani ze stowarzyszenia płk. Picota zgodzili się na ten - też dla nich zapewne niełatwy i traumatyczny - występ.

Powszechne nie tylko we Francji, ale i w całej Europie, także po przeciwnych stronach frontu, przerażenie użyciem gazów bojowych i straszliwymi tego efektami w wypadku Gance’a zaowocowało projektem filmu, który nie zatrzymał się na etapie scenariusza, lecz ostatecznie został zrealizowany - to wzmiankowane już Śmiercionośne gazy. Bohater filmu, chemik pracujący dla armii i wykorzystujący w swych badaniach między innymi jady chwytanych na innych kontynentach węży, o mało nie płaci najwyższej ceny za uprawianie nauki, którą można skierować przeciwko ludzkości: złoczyńcy omal nie uśmiercają jego syna przy pomocy jadowitego gada, a sabotaż w fabryce produkującej gazy bojowe według jego receptury sprowadza na pobliskie miasto toksyczną chmurę.

W sierpniu 1917 roku Gance powziął projekt realizacji trylogii filmowej, poprzez którą miał społeczeństwo edukować, podnosić jego poziom duchowy i moralny oraz głosić pokój. Miała ona obejmować trzy filmy: Oskarżam (J'accuse), Liga Narodów (La Société des Nations) i Blizny (Les Cicatrices). W roku 1919 jako konkretny film urzeczywistni się tylko ów pierwszy tytuł, pozostałe dwa zaś nigdy nie zostaną zrealizowane. Nie można jednak powiedzieć, iż Gance zarzucił projekt - pomysł „Stanów Zjednoczonych Świata” stanie się ważnym elementem fabularnym i ideowym filmów Koniec świata (1931) i Oskarżam (1937), zaś motyw „blizn” (w domyśle - wojennych) przeobrazi się we wstrząsający marsz „ludzi bez twarzy” w drugim z tych filmów. A kolejny pomysł, który przyjdzie reżyserowi-prorokowi do głowy jeszcze między sierpniem 1917 roku a rozpoczęciem realizacji pierwszego Oskarżam, to apokaliptyczno-dydaktyczny Koniec świata (La fin du monde). Ten przyoblecze się w konkretny kształt w roku 1931 wraz z realizacją katastroficzno-sensacyjno-pacyfistycznego filmu tak właśnie zatytułowanego. Gance nie podejmie wcześniej jego realizacji, bo praktyczny Charles Pathé skłoni reżysera, by zajął się najpierw projektem już najlepiej scenariuszowo i konceptualnie przygotowanym, i najbardziej aktualnym, jakim było Oskarżam: Tragedia epoki wspótczesnej (J'accuse: Tragédie des temps modernes)[12].

Film Oskarżam (1919) został podzielony na trzy części, wyświetlane na osobnych seansach. Powodem był chyba nie tyle istotnie dość

[11] Podobna intencja przyświecała zapewne Daltonowi Trumbo, autorowi powieści Johnny poszedł na wojnę (Johnny Got His Gun), jak i wyreżyserowanej przez autora jej wstrząsającej adaptacji z roku 1971.
[12] Por. L. Véray, op.cit., s. 23.
Il. 3. Kadr z filmu Oskarżam (1937). Les hommes sans visage 
długi czas projekcji (2 godziny 46 minut), bo widzowie tamtych lat oglądali już dłuższe filmy, jak chociażby trzygodzinne eposy Griffitha Narodziny narodu (1915) i Nietolerancja (1916), co raczej maksymalne komercyjne eksploatowanie filmu. I rzeczywiście, przywykli do formuły serialu kinowego francuscy widzowie nie omieszkali po zobaczeniu części pierwszej wybrać się na drugą i trzecią. Podział ten był jednak wbrew intencjom samego Gance’a, gdyż rozbijał jedność artystyczną dzieła, a zamiast na przekaz ideowy, kierował uwagę widzów na suspens fabularny - zresztą też niewątpliwy. Dopiero od roku 1921 pełna, integralna wersja filmu grana była na ekranach francuskich kin[13]. Część I rozpoczyna się na ulicach prowansalskiego miasteczka Orneval w pełną zabawy i tańca noc świętojańską 1914 roku. Zgrzytem wśród ogólnej radości jest ukazanie się rozbawionym mieszkańcom sowy. „Puszczyk w noc świętojańską, wkrótce nadejdzie kataklizm”[14] - obwieszcza napis w filmie. Na takim tle dowiadujemy się, że Édith Laurin jest obiektem gorącej i odwzajemnionej miłości poety Jeana Diaza, sama zaś jest nieszczęśliwa w małżeństwie. Jej mąż, François, brutalnie ją bije, a jest tak okrutny, iż każe swemu psu zlizywać z podłogi krew spływającą z upolowanej sarny, która leży na stole w salonie. Ujrzawszy ukradkiem schadzkę Jeana i Édith, strzela do ptaka, który pada martwy u ich stóp. Niedługo potem (w niedzielę, 2 sierpnia 1914 roku) miasteczko wrze na wieść o nadchodzącej wojnie: powołani mężczyźni pośród patriotycznych okrzyków rozentuzjazmowanych tłumów zgłaszają się do punktów mobilizacyjnych. Narodowe uniesienie ogarnia także François Laurina, choć jego niepokój budzi to, iż Jean ma zgłosić się do armii miesiąc później niż on sam. Zazdrosny o Édith, wysyła żonę do swoich rodziców w Alzacji, co okaże się fatalne w skutkach, gdyż ten pograniczny region został rychło zajęty przez wroga. Informacja o wzięciu Édith do niewoli i jej wywózce do Niemiec dociera do miasteczka i do frontowych okopów, gdzie stacjonuje Laurin. Na straszną wieść Jean reaguje prośbą do władz wojskowych o szybsze powołanie na front, François zaś wietrzy w niej kamuflaż dla „dekowania się" gdzieś Jeana Diaza z wiarołomną żoną (roztacza taką wizję w liście do teścia, rozpowiada o tym towarzyszom w okopach). Tymczasem Jean po przyspieszonym kursie oficerskim trafia na front jako dowódca kompanii Laurina. Nieufny i wrogi François bojkotuje jego rozkazy, a Jean nie śmie zastosować należnych sankcji. W końcu poeta-rywal zdobywa jednak zaufanie i szacunek François, gdy odbywa $\mathrm{z}$ sukcesem $\mathrm{w}$ jego zastępstwie niebezpieczną, niemal samobójczą misję, do której generał wyznaczył właśnie Laurina. Jean za swój wy-

[13] Ibidem, s. 53 .

[14] Zatem od razu na początku filmu ujawnia się alegoryczny tryb filmu, chętnie sięgający do takich zakodowanych kulturowo obrazów i obiektów. Puszczyk jest zresztą często wykorzystywany w filmie jako zły omen: przywołajmy na przykład jego ukazanie się nocą Dziewczynie, kiedy umarł jej Ukochany w Zmę- czonej Śmierci Fritza Langa, jego złowróżbne krzyki przed masakrą pasterzy-zabójców w Źródle Ingmara Bergmana czy przed pojmaniem Jezusa w ogrodzie Oliwnym w Pasji Mela Gibsona. Jego niesamowite pohukiwanie często też pojawia się w horrorach, tworząc aurę grozy i zwiastując niebezpieczeństwo. 
czyn otrzymuje jednocześnie Legię Honorową i karny areszt (heroizm był rezultatem niewykonania rozkazu generała). A François, odkrywszy wielkoduszność i męstwo Jeana, godzi się z faktem, iż obaj kochają tę samą kobietę. Pojednaniem rywali i ich rozmową o Édith kończy się część I.

Część II przenosi nas w rok 1918, „apogeum wojny", jak określa to napis wstępny. Zapadły wskutek trudów frontowych na zdrowiu Jean Diaz nie zamierza prosić o zwolnienie i tylko na wieść o chorobie matki wraca do rodzinnego miasteczka. Bardzo już

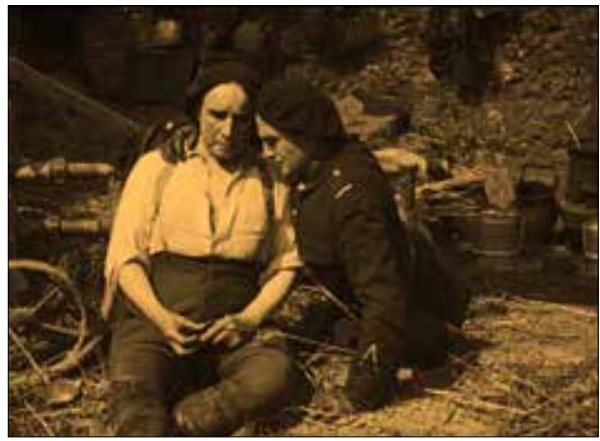

Il. 4. Kadr z filmu Oskarżam (1919). Krótkie frontowe pojednanie rywali niewoli Édith, przybywszy do Orneval z trzyletnią córeczką Angèle. Dziewczynka została poczęta w wyniku gwałtu dokonanego przez niemieckich żołnierzy. Na wieść o tym porywczy ojciec Édith, Maria Lazare, „niezłomny weteran roku 1870”, wyrusza w rynsztunku na front, by pomścić na Niemcach hańbę córki. Wkrótce do Orneval przybywa urlopowany François. Édith, w obawie o życie własne i córki, ukrywa przed nim jej tożsamość - dziewczynka przebywa w domu Jeana Diaza i ma być dzieckiem dalekiej krewnej poety, oddanym mu na przechowanie. Podejrzliwy François podstępem wydobywa od żony przyznanie się, iż to ona jest matką dziecka, a przekonany o ojcostwie Jeana, udaje się doń, by go zabić. Dramatyczną bójkę przerywa Édith, przedstawiając mężowi niemiecki dokument o pochodzeniu Angèle od nieznanego ojca i opowiada mu swą traumatyczną historię. Laurin, zrozumiawszy niesłuszność swych podejrzeń, mówi jednak Jeanowi, iż wróciwszy na front, nie miałby spokoju, wiedząc, iż w rodzinnym mieście Jean przebywa blisko Édith. Mimo słabego zdrowia Jean w obecności François pisze do władz wojskowych podanie o powrót na front i przydział w stopniu szeregowca - choć był oficerem - do kompanii sierżanta Laurina. Rozumiejąc bezinteresowne poświęcenie się rywala, François zamaszyście ściska mu dłoń, a przed ich wspólnym wyjazdem na front pozwala, by zakłopotani jego obecnością Jean i Édith się pocałowali.

Część III przenosi widza na front w samym środku intensywnych walk do okopów, w których znajdują się Jean i François. Trafiony w głowę, z obwiązanym bandażami czołem, Jean Diaz sprawia wrażenie kogoś, kto popadł w szaleństwo - albo proroka w starotestamentowej postaci. Z płomiennym wzrokiem, niepomny na rozrywające się wokół pociski, głosi towarzyszom w okopach wizjonerskie kazania. Obwinia w nich tych, którzy nie podejmują walki („Oskarżam tych, którzy śpią...”)[15], zachęca pomimo beznadziejności sytuacji do wytrwania („Wytrzymajcie jeszcze trochę, chłopcy... zwycięstwo jest blisko...

[15] Tu i dalej cytuję napisy z filmów we własnym przekładzie. 


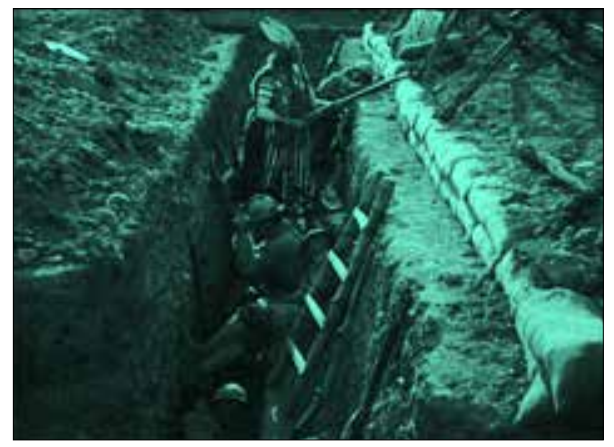

Il. 5. Kadr z filmu Oskarżam (1919). Alegoryczny Gal we francuskich okopach

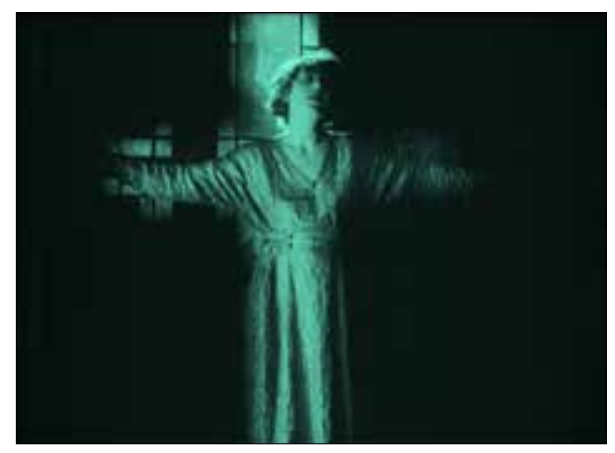

Il. 6. Kadr z filmu Oskarżam (1919). Jak ukrzyżowana - Édith alegorią kobiety-męczennicy lat wojny przed wami, z rozpostartymi skrzydłami. Tak mi powiedział Gal"), roztacza przed francuskimi żołnierzami wizję mitycznego przodka, Gala, który stoi obok każdego z nich („Śmiało, chłopaki! Gal jest z nami”).

Narracja filmu tego alegorycznego patrona Francji, w stroju niczym z komiksów o Asteriksie[16], wizualizuje w podwójnej ekspozycji. W ogóle narracja filmu staje się coraz mniej skupiona na fabularnych losach głównych postaci i stopniowo przechodzi w inne rejestry: najpierw paradokumentalny, poprzez staranną obrazową rekonstrukcję walk i warunków życia w okopach oraz zapewnienia, iż cytowane w napisach fragmenty listów żołnierzy kompanii Laurina i Diaza pochodzą z autentycznej korespondencji z frontu, później zaś uogólniającego dyskursu, posługującego się metafizycznym konceptem i alegoryczną stylistyką. I tak na przykład gdy narracja przenosi nas z frontu do Orneval, by pokazać, co się dzieje z Édith, to w pierwszej chwili wydaje się, iż chwyt montażu symultanicznego przemieszcza nas w inną przestrzeń, byśmy poznali, co równocześnie dzieje się gdzieś indziej. Napis poniekąd nas w tym utwierdza, przypominając fabularne komplikacje położenia bohaterki: „Cierpienie osaczało Édith z każdej strony, z której jej serce się wycofywało: żona François, ukochana Jeana, córka Marii Lazare’a, matka Angèle”. Ale narracja nie rozwija przed nami obrazów i sytuacji, ukazujących owe cierpienia, zadowalając się ujęciem, w którym na tle rozświetlonego gdzieś zewnętrznym pożarem okna Édith, stojąc z rozłożonymi rękami, wygląda jak ukrzyżowana.

Dwa kolejne napisy, o charakterze nie informacji fabularnej, lecz alegoryzującej interpretacji, potwierdzają to odczytanie: „Krzyż poświęcenia, sumujący wszystkie boleści francuskich kobiet” i „Uderz znów, o Boleści, jeśli znajdziesz miejsce! Lamartine”. Uczyniwszy z Édith metonimiczną czy też synekdochiczną reprezentację wszystkich francuskich kobiet doznających cierpień podczas wojny, narracja nie poświęca więcej uwagi jej losom i wraca na front. A na froncie toczy się decydująca bitwa, w której kompania naszych bohaterów skazana jest na zagładę - z czego żołnierze zdają sobie sprawę, śląc do domu pożegnalne listy. Obrazy apokaliptycznych walk zostają uwiarygodnione przez napis, nadający im status paradokumentalnej rekonstrukcji: „Sceny ataku na sektor St-Mihel[17] były sfilmowane przy współpracy żołnierzy francuskich i amerykańskich, w szczególności 28. Dywizji
[16] Tak my dziś skłonni jesteśmy rozpoznawać figurę Gala w świetle popularnego cyklu utworów kultury masowej; w latach I wojny światowej francuska propaganda wojenna przywoływała (między innymi na plakatach) postać Wercyngetoryksa, wodza Galów walczącego z Juliuszem Cezarem. „Gal” z filmu Gance’a ikonograficznie konotował ówczesnym widzom tę właśnie postać. Por. L. Véray, op.cit., s. 40. [17] Taka nazwa figuruje na planszy. Dziś miejscowość ta nazywa się Saint-Mihiel. 
amerykańskiej w miasteczkach d'Hatton-Chatel, Seicheprey i Mousec, rozsławionych przez nią". François uznaje, iż Jean, który go nie rozpoznał, oszalał, i rozkazuje noszowym wynieść go z pola walki. Wkrótce obaj, ciężko ranni, leżą w szpitalu polowym na sąsiednich łóżkach. Umierający Laurin podaje Diazowi rękę - uścisk dłoni żywego i martwego rozdziela dopiero lekarz. Po powrocie poety do rodzinnego miasteczka narracji filmu nie interesują dalsze losy bohaterów - ku rozczarowaniu i przerażeniu Édith poeta nie rozpoznaje dawnej ukochanej, wypytuje o sąsiadów, mówi jej o jakiejś tajemniczej misji, jaką mu powierzono. Sprasza na wieczór do domu Édith wszystkich mieszkańców Orneval i roztacza przed nimi wielką wizję, która - tak sugerują montaż, miseen-scène i napisy - zdaje się materializować przed oczyma słuchaczy. Wizja ta porusza wewnątrzdiegetyczne audytorium do łez, budzi ich przerażenie, skłania do rachunku sumienia i pokuty, a na koniec każe zastanawiać się nad jej ontycznym statusem - była zmaterializowanym cudem czy też tylko omamem, urojeniem, hipnotyczną sugestią? „Czy śniliśmy?... Czy to jakaś potężna sugestia? W czyjej mocy byliśmy?” napis ten przekazuje wątpliwości Édith, ale wyraża on zarazem niepokój całego audytorium, które w domu ukochanej zgromadził poeta[18].

Wizja ta w zasadzie wieńczy film i wydaje się centrum jego przesłania ideowego. Napis poprzedzający tę centralną, a zarazem kulminacyjną i przedostatnią sekwencję filmu, zapowiada "Le Grand Soir” (Wielki Wieczór). Wezwani do domu Laurinów mieszkańcy Orneval w „zasłuchaniu” i „zapatrzeniu” znieruchomieli naprzeciw Jeana, który w prorockim uniesieniu zaczyna snuć swą opowieść: „Tamtego wieczoru byłem na warcie na polu bitwy, wszyscy wasi zmarli tam byli... wszyscy wasi drodzy zmarli... wszyscy, wszyscy...”.

Narracja filmu wizualizuje wizjonerskie obra-

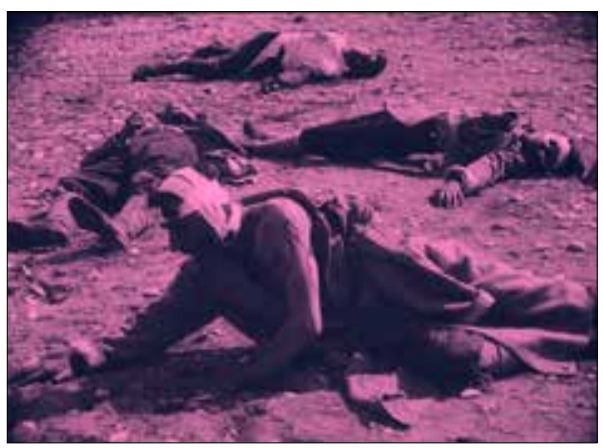

Il. 8. Kadr z filmu Oskarżam (1919). Zmartwychpowstanie François Laurina czały. Jeden ze zmarłych (rozpoznajemy w nim François Laurina) powstaje z martwych i woła: „Przyjaciele, nadeszła pora, by dowiedzieć się, czemu służyła wasza śmierć! Zobaczmy, czy kraj jest godny naszego poświęcenia: Zbudźcie się!...”.

[18] Mam nieodparte wrażenie, iż wzbudzona przez Jeana Diaza przed mieszkańcami miasteczka wizja pochodu zmartwychwstałych poległych musiała zainspirować zastanawiająco podobne sceny w filmach Fritza Langa, które powstały zaraz po pierwszym Oskarżam (1919): myślę tu o pochodzie zmarłych, który widzi Dziewczyna w filmie Zmęczona Śmierć (Der müde Tod, 1921), oraz o fantomatycznej karawanie, jaką Sandor Weltmann wyczarowuje widzom filharmonii w filmie Doktor Mabuse, gracz (Dr. Mabuse, der Spieler. Zweiter Teil: Inferno - Ein Spiel von Menschen unserer Zeit, 1922). 


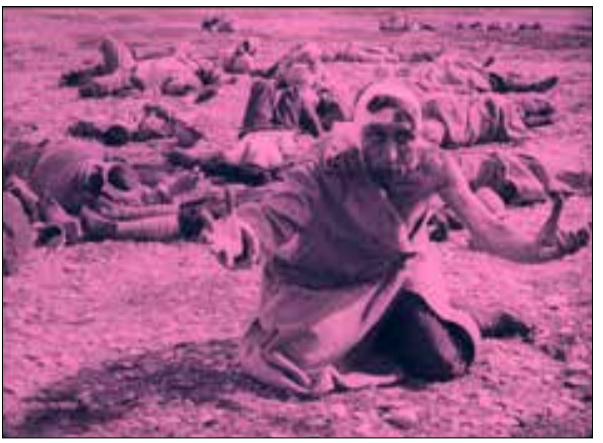

Il. 9. Kadr z filmu Oskarżam (1919). Zmartwychpowstały François wzywa innych poległych do przebudzenia

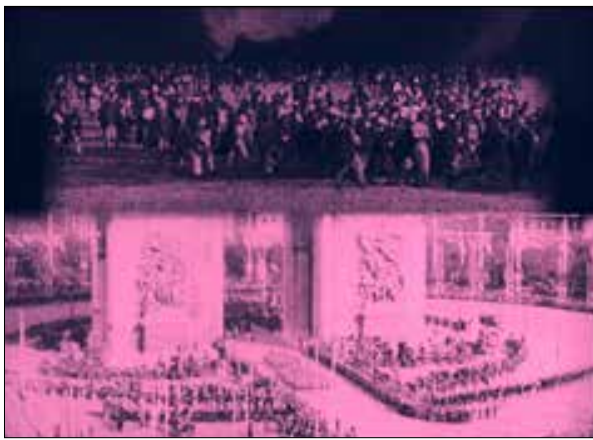

Il. 10. Kadr z filmu Oskarżam (1919). Poliwizja - pochód zmartwychpowstałych żołnierzy ponad defiladą zwycięstwa w Paryżu
„I zmarli posłuchali! Powiadam wam, posłuchali!..." - kontynuuje Jean, a narracja filmu wizualizuje pochód zmartwychwstałych ciał idący „ku widzom”, tak wewnątrz-, jak i zewnątrzdiegetycznym. „Mieli ciała pokryte ziemią i oczodoły pełne gwiazd. Przybywali niezliczeni zza horyzontu jak wezbrane fale" - tak ów pochód komentuje poeta-wizjoner.

Słowa Jeana „A tymczasem żywi maszerowali do muzyki” zuchwale ilustruje montaż równoległy, o charakterze zarazem montażu symultanicznego, jak i paralelnego ideowego: pochód zmarłych kontrapunktują dokumentalne zdjęcia parady zwycięstwa armii francuskiej pod Łukiem Triumfalnym w Paryżu. Chwilę później split-screen, rozcięty wzdłuż osi horyzontalnej, ukazuje pochód zmartwychwstańców nad dokumentalnym obrazem parady zwycięstwa na - nomen omen - Polach Elizejskich.

„Nieznani polegli... wszyscy umarli... wszyscy wielcy zmarli... też maszerowali..." - komentuje ów obraz Jean. Jean opowiada o swej ucieczce przed niesamowitym pochodem, a jego słuchacze, którzy w przerażeniu próbują się wydostać z domu Édith, zostają przez niego powstrzymani. „Stójcie! Nie wyjdziecie, póki mnie nie wysłuchacie... Jeśli byliście wierni waszym poległym, nie macie się czego obawiać”. Jednak obecni mają się czego obawiać: jedną z kobiet Jean obwinia o złe prowadzenie się pod nieobecność męża, młodego mężczyznę o marnotrawienie majątku ojca, kilka innych osób o czerpanie „nikczemnych zysków ze śmierci waszych mężów, waszych braci, waszych synów” i „haniebne bogacenie się na wojnie”. Narracja wizualizująca te oskarżenia unaocznia widzom - ale i chyba słuchaczom Jeana - te niewątpliwe winy. Sześciokrotnie pada słowo, które jest tytułem filmu: „Oskarżam!”. Przerażeni tą „kapitułą win” mieszkańcy Orneval jeszcze raz próbują wydostać się $\mathrm{z}$ domu Laurinów, ale zagradza im drogę zmaterializowany nagle pochód zmartwychwstałych poległych podążający na wprost nich. Zatrzymani uciekinierzy wycofują się z powrotem do domu, zapłakani i przerażeni klękają, przyjmują pokutne pozy i gesty, obserwując zmarłych przez drzwi i okno. W oknie ukazują się ojciec i mąż Édith. „Maria Lazare! François!” - woła przerażona bohaterka... Tymczasem po tym „objawieniu” zmarli zaczynają się tyłem wycofywać (ruch odwrócony). Ich bliscy chcą za nimi pobiec, ale znów powstrzymuje ich Jean Diaz. „Nie przysparzajcie im cierpienia, wywołując ich, pozwólcie im odejść. Widzicie, oni błagają, byście pozostali dzielni! Są szczęśliwi, że znowu was ujrzeli i powrócą do swego spokojnego snu, wiedząc, że nie na próżno poświęcili swe życie... Podejmą na nowo swe krzyże, które teraz stały się lżejsze"[19]. Zmarli odwracają się teraz od widzów,

[19] Przekład skomasowanego tekstu napisów z trzech kolejnych plansz. 
a każdy z nich bierze na ramiona krzyż. Kamera obserwuje oddalający się w głąb kadru pochód, a obraz w coraz bardziej zmniejszającej się diafragmie irysowej stopniowo przechodzi w całkowitą czerń, aż diafragma irysowa ponownie otwiera się, ukazując jako jedyny przedmiot w obrazie krzyż z pleców któregoś ze zmartwychwstańców.

Ten finałowy obraz ewokuje oczywiście konotacje chrześcijańskie, podobnie zresztą jak sama idea zmartwychwstania ciał. Wielki Wieczór w domu Laurinów ma w takim kontekście coś z sądu ostatecznego, choć sam Jean Diaz przypomina raczej proroka w typie Jeremiasza czy Jana Chrzciciela niż Michała Archanioła. Słowo jaccuse, „oskarżam”, pojawia się w napisach od powrotu Jeana do rodzinnego miasta do finału Wielkiego Wieczoru aż dziewięć razy. Ostatni raz, kiedy po opuszczeniu domu przez mieszkańców miasteczka Édith spostrzega, jak prowadzona przez jej córeczkę dłoń poety wypisuje kredą na drzwiach szafy słowo J'accuse. To wtedy właśnie bohaterka uświadamia sobie nieodwołalną utratę ukochanego i jego pogrążenie w szaleństwie.

Kogo i o co właściwie oskarża Jean Diaz, a tym samym Abel Gance, skoro jako artysta pełni on funkcję porte parole reżysera? Warto zwrócić uwagę na samą tę frazę: J'accuse - francuskiej publiczności A.D. 1919 musiała ona kojarzyć się jednoznacznie z tytułem słynnego listu otwartego Emila Zoli, opublikowanego 13 stycznia 1898 roku na łamach dziennika „L’Aurore”, który ujawnił mataczenia wojskowego aparatu sprawiedliwości w sprawie Dreyfusa, motywowane ukrytym antysemityzmem, tuszowaniem własnej nieudolności i błędów, i obroną źle pojętego „honoru armii”[20]. Gance, inaczej niż Zola, raczej nie oskarża armii, tym bardziej że do realizacji sekwencji batalistycznych i pochodu zmartwychwstałych poległych Gance uzyskał zezwolenie na udział w nich żołnierzy czynnych. W czołówce filmu tytułowy napis J’ACCUSE ułożony jest $\mathrm{z}$ ciał żołnierzy.

Do Zoli nawiązuje przede wszystkim częstotliwość użycia tej

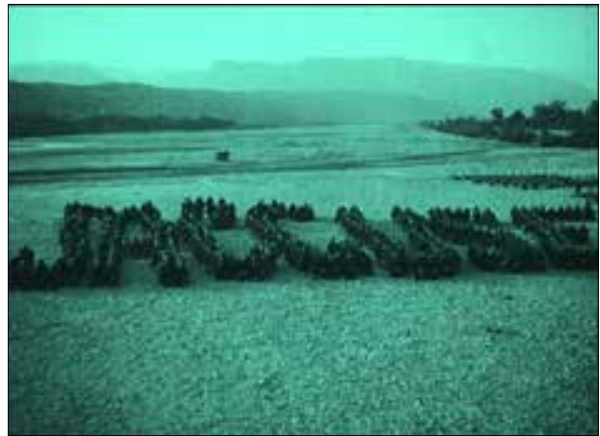

Il. 11. Kadr z filmu Oskarżam (1919). Czołówka tytuł filmu ułożony z ciał żołnierzy frazy, choć, inaczej niż w artykule pisarza, nie następują po niej imiona i nazwiska konkretnych oskarżonych. Rzucone niejako w próżnię słowo "oskarżam” (nie licząc czołówek wszystkich trzech części, pojawia się ono w całym filmie w sumie dwadzieścia razy) ilustrują obrazy przedstawiające „okropności wojny”: zniszczone miasta i domostwa, ciała poległych, opłakujące mężczyzn i kobiety. Na tle takich oto obrazów pojawia się to słowo w filmie po raz pierwszy, rzucone przez Jeana, który - jeszcze w cywilu - konfrontuje dochodzące doń wieści o rozmaitych nieszczęściach wojennych z sielskimi obrazami swych poematów. Narracja filmu ilustrowała wcześniej jego poetycki tom Les Pacifiques sek-

[20] Słynny tekst Zoli przypomniał ostatnio Roman Polański zarówno w fabule, jak i poprzez sam tytuł oryginalny swego filmu traktującego o sprawie Drey- fusa Oficer i szpieg (J’accuse, 2019). Polański nawiązuje wyłącznie do Zoli, z pewnością zaś nie do Gancea. 
wencją pięciu nieruchomych malowanych obrazów, przedstawiających sielskie obrazki wiejskie: pasterza owiec, siewcę, orkę, kobietę z chłopcem niosących chrust, rybaków niosących połów. Postacie ukazane były pod światło jako ciemne, konturowe sylwetki na tle wschodzącego czy zachodzącego słońca. Podobna sekwencja dwunastu, już niewątpliwie filmowych, obrazów o dużej fotogenii, ewokowała centralny poemat tomu, Odę do Słońca; kontrowe zdjęcia pod światło ukazywały morze, skały, nadmorskie sosny na klifach. Jeden z kadrów, z żaglówką na tle rozświetlonego zachodzącym czy wschodzącym słońcem morza, wydawał się niemal cytatem znanego obrazu Claude’a Moneta. W sekwencji ostatnich czterech ujęć ilustrujących Odę na sielskie, rozsłonecznione krajobrazy nałożona była w podwójnej ekspozycji sylwetka Édith, radosnej, tańczącej, w jasnej sukience. Nie przytaczając słów poematów, narracja w ten sposób oddawała ich „treść” i „ducha”. Rozwiązanie to trzeba uznać za wręcz modelowe dla estetyki francuskiego impresjonizmu filmowego - a przecież Oskarżam (1919) to jedno z czołowych osiągnięć artystycznych tego nurtu. I w podobny sposób pełne grozy kadry ze zbombardowanymi budynkami, trupami na polu bitwy czy opłakującymi zmarłych kobietami ilustrują strumień świadomości poety, który - przerażony apokaliptycznymi zniszczeniami - „oskarża”. Po raz drugi Jean „oskarża” na wieść o wzięciu do niewoli i uprowadzeniu Édith. Na planszy napis kapitalikami J'ACCUSE utworzony jest ozdobnymi secesyjnymi literami, w których rozmaite kształty układa się ciało zniewolonej, skrępowanej więzami kobiety. Po tym oskarżeniu Diaz decyduje się wyruszyć na front wcześniej niż wyznaczała mu to mobilizacyjna kolejność. Kolejny raz Jean wypowiada oskarżenie w rodzinnym domu, do którego wrócił na wieść o chorobie matki. Urlopowany z frontu, zdążył jeszcze na prośbę matki odczytać-wyrecytować znane już nam z przekładu na filmowe obrazy swe „słoneczne” utwory. Gdy matka w trakcie ich lektury-recytacji umiera, „zabierając do grobu jego świetliste strofy”, poeta postanawia dokończyć swój nieukończony hymn. "Ale nie znalazł nic ponad smutek zmierzchu, nawiedzanego przez słodkie widmo Édith” - mówi nam napis. Toteż owe „zmierzchowe” strofy narracja ilustruje mrocznymi, melancholijnymi krajobrazami, przedstawiającymi cmentarne cyprysy czy zimę, a „słodkie widmo" ukochanej w podwójnej ekspozycji snuje się po nich w ciemnych, żałobnych szatach. Narracja napisem na planszy, na który nałożony jest obraz tańca szkieletów, uogólnia śmierć Madame Diaz, czyniąc z niej, podobnie jak poźniej z Édith, reprezentantkę kobiet-męczennic lat wojny: „Wojna zabiera tyleż matek, co i synów”. Nad ciałem martwej matki rzuca po raz trzeci swoje „Oskarżam!” A czwarty raz wypowie je jeszcze tego samego wieczoru, gdy przemoczona Édith wróci do domu z nieślubnym dzieckiem i opowie jemu oraz ojcu o zbiorowym jej zgwałceniu przez niemieckich żołnierzy (narracja dramatyczne wydarzenie zilustruje metonimicznie poprzez kadr, w którym ekspresjonistyczne olbrzymie trzy cienie żołdaków w charakterystycznych pruskich hełmach ze szpicem pochylają się nad kulącą się ze strachu na sianie bohaterką). 
Wstrząśnięty Jean woła: „Oskarżam”, a narracja ponownie przedstawia nam secesyjne kapitaliki napisu J'ACCUSE utworzone przez rozmaite pozycje skrępowanej więzami kobiety; tym razem znajdują się one nad obrazem topielicy w białej sukni, ewokującej Ofelię.

Po raz piąty i ostatni przed Wielkim Wieczorem słowo J'accuse pojawia się podczas lekcji francuskiego dawanej przez Jeana małej Angéle. Pisać to właśnie słowo kredą na drzwiach szafy uczy poeta córkę Édith, prowadząc rękę dziewczynki. Scena ta znajdzie dramatyczny kontrapunkt na koniec Wielkiego Wieczoru, gdy to ręka Angéle prowadzić będzie podczas pisania J'accuse dłoń poety.

Wielki Wieczór to centralna, kulminacyjna i „najpotężniejsza” scena filmu, ale po niej następuje jeszcze finalna koda: Lendemain, „nazajutrz". Jeanowi wpada w ręce rękopis jego poetyckiego tomu Les Pacifiques. Oszalały poeta wyrywa z zeszytu kartki, mnąc i drąc je w amoku, a napis dookreśla nam jego stan: „Żołnierz zabił w nim poetę i śmiał się z wariata, który kiedyś pisał swe wiersze o pokoju pod słońcem i o słodyczy życia”. Gdy promień słońca wpada do ciemnego pokoju, Jean gwałtownie zwraca się ku oknu i do słońca na niebie kieruje swą nową, pełną jadu i goryczy Odę. Co ciekawe, narracja filmu nawet nie próbuje tym razem wizualizować w impresjonistycznym stylu zawartości poematu, pokazując tylko na przemian Jeana wykrzykującego w emocjach wiersz przed oknem i plansze z kolejnymi partiami poematu. Warto może przytoczyć go tu in extenso, sumując tekst $\mathrm{z}$ kolejnych plansz:

Posłuchaj mnie choć trochę, słońce, zanim, zniknąwszy wśród umarłych, odejdę dziś wieczorem. I jeśli moja ręka przylgnie do ramy okna, to aby - gorzki kaprys! - miast umrzeć, być w miejscu, gdzie ci śpiewam. Niespłacone moje długi wobec ciebie. Oskarżam cię, że pomimo wspaniałości dnia ubrałoś ohydę w świetlistą szatę, idąc niewzruszenie twą niebieską drogą, nie drżąc ze zgrozy w swym majestacie. W śmierci przeklinam cię, Królu Straszliwej Nocy. Był sobie poeta, od festonów i astragali, roześmiany geniusz jaśniał w mym obliczu! Powróciłem, żołnierzu, posąg pijany i widmowy, z mego grobu; krzyczę, odsuwając płytę, jakby jęknęła sama ziemia. Wysłuchaj mnie w imię tych, których zwiódł twój splendor! Boisz się? Rumie-

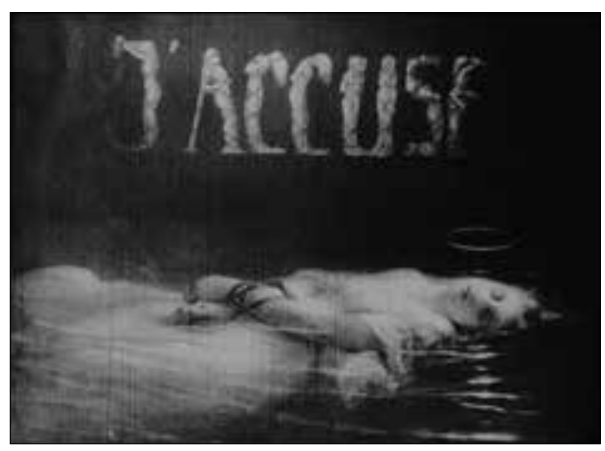

Il. 12. Kadr z filmu Oskarżam (1919). Metonimicznie ukazany gwałt niemieckich żołnierzy na Édith Laurin

Il. 13. Kadr z filmu Oskarżam (1919). Oskarżenie zapisane alegoryczno-secesyjną czcionką nad „Ofelią"

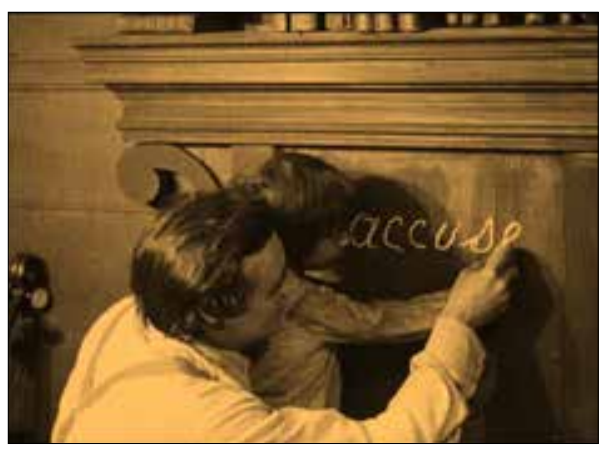
nisz się! Nazywam się Jean Diaz, ale zmieniłem mą Muzę. Moje niegdyś słodkie imię brzmi teraz: Oskarżam! I oskarżam ciebie, słońce... Oświetlasz straszliwą epopeję nieme, spokojne, bez wstrętu, jak okropna twarz Il. 14. Kadr z filmu Oskarżam (1919). Lekcja francuskiego $\mathrm{z}$ wyrwanym językiem, patrzysz na to $\mathrm{z}$ sadyzmem $\mathrm{z}$ twego lazurowego balkonu do samego końca! 
Wykrzyczawszy poemat, poeta pada nieprzytomny, a wpadający przez okno do ciemnego wnętrza promień słońca oświetla jego leżące na podłodze ciało. Tym obrazem kończy się film.

Ton ody Jeana Diaza przypomina intensywnym słowotokiem poemat Guillaume’a Apollinaire’a Strefa (Zone), a obraz słońca jako „okropnej twarzy z wyrwanym językiem” (une face horrible à la langue Coupée) ewokuje wspaniałą, niepokojącą pointę Strefy: „Żegnaj żegnaj/ Słońce szyjo ścięta" (Adieu adieu/ Soleil cou coupé). Skojarzenie jest chyba nieprzypadkowe. Znany powszechnie jest portret Apollinaire’a $z$ okresu tuż przed jego śmiercią na hiszpankę, przedstawiający poetę $z$ obandażowaną po wojennej ranie głową. Jean, który przed wojną i podczas niej nie nosił brody, po powrocie $\mathrm{z}$ wojny wystylizowany został ewidentnie na Apollinaire’a właśnie poprzez charakterystyczną bródkę i obandażowaną głowę. W poetyckim świecie Strefy, w którym kalejdoskopowa nowoczesna rzeczywistość zachwiała wszystkimi systemami i wartościami, i w którym sens zdają się mieć jedynie fizyczne doznania, jako znak ocalenia i ostatnia deska ratunku wskazany jest Chrystus i chrześcijaństwo. Choć poemat Jeana wydaje się jeszcze bardziej obrazoburczy i pesymistyczny niż Strefa, wręcz nihilistyczny, to jednak w samym filmie Gance’a pointą najważniejszej sceny - pochodu zmartwychwstałych poległych podczas Wielkiego Wieczoru - jest właśnie krzyż, niewątpliwy emblemat zwycięskiego, zmartwychwstałego Chrystusa.

Powróćmy jednak do postawionego wcześniej pytania: kogo i o co właściwie oskarża Jean Diaz, a tym samym Abel Gance? Oczywiście, oskarżenie rzucone przez poetę Słońcu jest jedynie metaforą oskarżenia „naturalnego porządku rzeczy”, którego znakiem i gwarantem jest poniekąd słońce. Ale czy tym samym nie jest to oskarżenie Boga jako porządku tego stwórcy? Boga, który pozwala na masową śmierć, apokaliptyczne zniszczenia, niewyobrażalne cierpienia fizyczne i duchowe? Oczywiście, pytania te wrócą ze zdwojoną siłą po II wojnie światowej, której apokaliptyczny wymiar - co w 1919 roku mogło się wydawać nie do pomyślenia - znacznie przekroczy grozę Wielkiej Wojny 1914-1918, jak wówczas nazywano jedyną dotąd wojnę światową. Wydaje się jednak, iż film i Gance nie czynią tego kroku, by oskarżyć Boga i chrześcijaństwo, skoro afirmują - mimo wszystko - krzyż. Nienazwane w oskarżeniu źródło zła jest jednak, jak sądzę, w paru scenach wskazane, a intuicje Gance’a zdają się współbrzmieć z teorią antropologiczną René Girarda, którego wszystkie w zasadzie prace traktują ciągle - choć za każdym razem równie fascynująco i odsłaniając coraz to nowe aspekty - o jednym: o tak zwanej mimetycznej przemocy w kulturach i społecznościach przed- i niechrześcijańskich, w każdym razie takich, które nie wpisały w swoje mechanizmy regulujące przykazań danych przez Jezusa. Nieuwewnętrznienie zarówno przez jednostkę, jak i społeczności tych zasad prowadzi do eskalacji przemocy, wzajemnej wojny wszystkich ze wszystkimi (tak zwany kryzys mimetyczny) i do rozwiązania kryzysu poprzez jednoczącą społecz- 
ność przemoc wobec innych: jakiegoś narodu, klasy społecznej, grupy czy jednostki, wskazanej jako winowajca i skazanej na bycie kozłem ofiarnym. Te nieodzowne dla uniknięcia kryzysu mimetycznego, dla niedopuszczenia do zapanowania władztwa szatana (Girard absolutnie serio, bez cudzysłowu, traktuje kategorię osobowego, metafizycznego zła), reguły, to: 1) rezygnacja z pożądania tego, co posiadają lub czego pożądają inni, i z dążenia do niepohamowanego zaspokajania swych pragnień: materialnych, seksualnych, związanych ze społecznym statusem; 2) wyrzeczenie się dążenia do górowania czy panowania nad innymi; 3) wyrzeczenie się stosowania przemocy i wszelkiej siły wobec drugich, nawet pozornie uzasadnionej - jak na przykład w wypadku odpłaty za uczynione zło; 4) rezygnacja z kierowania się wyłącznie więziami partykularnymi - z własnym narodem, klasą, jakąś grupą, rodziną - na rzecz prymatu uniwersalnej więzi miłości z ludzkością i z każdym człowiekiem z osobna: „miłujcie nieprzyjacioły swoje”. Girard, analizując przekazy rozmaitych kultur (na przykład ich mity czy dokumenty historyczne) i wielkie dzieła literackie (Szekspira, Balzaca, Dostojewskiego, Prousta), oraz konfrontując je z przekazami staroi nowotestamentowymi, ujawnia fundamentalną w historii ludzkości rolę chrześcijaństwa w zdemaskowaniu i częściowym przynajmniej powstrzymaniu mimetycznej przemocy[21]. Kultura porewolucyjnej Francji, choć z pewnością nie jest „przedchrześcijańska”, po wyrugowaniu z życia publicznego i państwowego wymiaru religijnego w procesie przymusowej laicyzacji chrześcijańska, przynajmniej w znacznej mierze, przed wybuchem I wojny światowej już nie była.

Historia małżeńskiego trójkąta, zajmująca tak wiele miejsca w sjużecie pierwszego Oskarżam, choć wydaje się „nie pasować” do antywojennej wymowy filmu, w kontekście koncepcji Girarda jest tu jednak jak najbardziej na miejscu. Trójkąt małżeński to na podstawowym mikropoziomie społecznym układ „trójkątnego pożądania”; zmultiplikowany na poziomie ogólnospołecznym choćby poprzez rozluźnienie etyki seksualnej i unieważnianie więzi rodzinnych może generować wskazany przez Girarda „kryzys mimetyczny”. W filmowym trójkącie winny wydaje się brutalny François; być może jednak źródłem tej brutalności nie jest „charakter” Laurina, lecz impulsywne przy temperamencie cholerycznym kompensowanie sobie faktu, iż żona go nie kocha, a on - jako mąż - do tej miłości ma prawo (tak przynajmniej sądzi). Poprzez prawo nie można jednak zapewnić sobie czyjejś miłości, a brutalna reakcja powoduje tylko nienawiść Édith. W małżeństwie Laurinów dochodzi właśnie do „kryzysu mimetycznego” poprzez lawinowe narastanie niemiłości Édith - brutalności François - jej nienawi-

[21] Po polsku ukazało się już sporo prac Girarda. Wydaje mi się, że najlepszym wprowadzeniem w jego myśl jest blok materiałów w monograficznym numerze „Literatury na Świecie” 1983, nr 12 (149), a spośród książek: Kozioł ofiarny, przeł. M. Goszczyńska, Łódź
1987; Prawda powieściowa i kłamstwo romantyczne, przeł. K. Kot, Warszawa 2001; Widziałem szatana spadającego z nieba jak błyskawica, przeł. E. Burska, Warszawa 2002; Sacrum i przemoc, przeł. M. i J. Plecińscy, Kraków 2019. 
ści - jego coraz większego gniewu. Sytuację pogarsza „ten trzeci”, czyli Jean, mimo napomnień matki niepotrafiący wycofać się z pożądania Édith. Jednoczesne pożądanie przez dwu mężczyzn tej samej kobiety musi zrodzić ich rywalizację i wzajemną niechęć, jeśli już nie nienawiść. Zazdrosny o żonę i możliwość jej romansowania podczas jego pobytu na froncie $\mathrm{z}$ „dekownikiem”, wysyła ją mściwie, ale też bezmyślnie, do swych rodziców w Alzacji, w region najzaciętszych walk, gdzie Édith rzeczywiście przejdzie gehennę. To chyba moment największego uprzedmiotowienia żony przez Laurina i największa krzywda, jaką jej wyrządził. François, choć przez frontowe wyrzeczenia i konieczność poświęcania się dla innych w znacznej mierze wyzbył się swego brutalnego charakteru, nie może jednak zaakceptować rywala jako przełożonego - stąd jego ostentacyjne, narażające go na regulaminowe kary, lekceważenie oficerskiego statusu Diaza. Przełamuje się jednak i akceptuje go jako żołnierza i jako człowieka - a także jako mężczyznę, który kocha tę samą kobietę, co on - gdy odkrywa, iż wykonując za niego niebezpieczną misję nie tylko być może uratował mu życie, ale i sam naraził się na areszt za niesubordynację wobec rozkazu generała. Podczas urlopu François żona nie tylko nie zauważa jego przemiany na lepsze, ale nawet nie potrafi mu okazać najprostszej czułości, frontowemu weteranowi zapewne niezbędnej. Rodzi to w nim ponownie gniew, eksplodujący po odkryciu, iż Édith i Jean odgrywają przed nim komedię co do tożsamości Angéle, gotowością zabicia rzekomego ojca dziecka - czyli Jeana. Dopiero przekonany niemieckim świadectwem urodzenia uspokaja się, ale wymusza na Jeanie oddalenie się od Édith. Jean aż z naddatkiem (być może wskutek poczucia winy) wypełnia ten warunek, zgłaszając się na front jako prosty szeregowiec pod rozkazy rywala. Wzruszony tą wielkodusznością François nie tylko zachęca żonę i Jeana do pocałunku przed ich wspólnym wymarszem na front, ale w okopach roztacza nad Diazem czujną opiekę. Zauważywszy szaleństwo Jeana (poeta, nie rozpoznawszy Laurina, wyznał mu, iż w tajemnicy przed nim wysłał do Édith serię listów), rozkazuje noszowym wynieść go z pola walki, na którym sam odniesie śmiertelne rany. Próby zaniechania mimetycznej przemocy oraz przerwania spirali niechęci, zazdrości i gwałtowności w trójkącie małżeńskim Laurinów i Jeana Diaza, nie udają się z racji „niezgrania w czasie” (bad timing) dobrej woli i wyrzeczeń każdej ze stron, toteż do końca trójkąt ten pozostaje nierozwiązanym węzłem gordyjskim (i po gordyjsku zostaje przecięty śmiercią męża i szaleństwem kochanka).

Pożądanie mimetyczne na makropoziomie - międzynarodowych podmiotów takich jak państwa - grozi konfliktami wojennymi i rozpętaniem kryzysu na skalę globalną. W relacjach francusko-niemieckich rolę tego nieszczęsnego przedmiotu pożądania spełniły dwie francuskie prowincje, Alzacja i Lotaryngia. Utracone przez Francję na rzecz nowo powstałego Cesarstwa Niemieckiego po przegranej wojnie francusko-pruskiej 1870-1871 przyczyniły się do nasilenia przed I wojną światową we Francji nastrojów rewanżystowskich i buńczucznych za- 
powiedzi ich odebrania. Co, rzecz jasna, powodowało kontrakcję sąsiedniego mocarstwa, jego zbrojenia, militarne sojusze i antyfrancuską propagandę. Entuzjazm Francuzów 2 sierpnia 1914 na wieść o wypowiedzeniu Niemcom wojny i powszechnej mobilizacji został w filmie Gance’a zobrazowany przez euforię, jaka ogarnia tego dnia prowansalskie miasteczko Orneval, gdy wiwatujący tłum towarzyszy mężczyznom zgłaszającym się do punktów mobilizacyjnych. François woła „Nareszcie!”, jakby rad, że w wojnie znajdzie ujście dla swych brutalnych instynktów, a ojciec Édith, Maria Lazare, weteran przegranej wojny roku 1870, nie może tej nowej wojny się doczekać, by odbić wreszcie utracone Alzację i Lotaryngię. Mapę z zaznaczonymi czarno obiema prowincjami ojciec Édith nieustannie kontempluje i prowadzi na niej wraz z innymi weteranami „zwycięskie” kampanie.

Zestawiając dramatyczne walki na froncie z przesuwaniem choragiewek na mapie przez grono starszych panów, narracja filmu pozwala sobie na gorzką ironię, wzmocniwszy ją takim oto napisem: „Tymczasem na froncie domowym weterani wygrywali każdą bitwę”. Ten „front domowy” załamie się, gdy podczas jednej z jego „kampanii” starszy pan otrzyma telegram $z$ informacjami o uprowadzeniu córki przez wroga i o tym, iż to wróg, a nie „nasi”, poczynił postępy na froncie, wdzierając się na francuskie terytorium.

W dniu wybuchu wojny małe dzieci nic o niej nie wiedzą. Dziewczynka, pytana, co to jest wojna, odpowiada: „Nie wiem”. W roku 1918 dzieci w wojnę się bawią: biorą jeńców, nakładając przepaskę na oczy, urządzają egzekucję „wroga”, a może „szpiega”, przeganiają „Prusaka”.

Rolę kozła ofiarnego (to mechanizm wszechstronnie w pracach Girarda zanalizowany) pełni trzyletnia Angéle. Z nałożonym na jej małą główkę wziętym skądś przez dzieci hełmem niemieckiego żołnierza odgrywa narzuconą jej przez starsze i silniejsze dzieci rolę „wroga”, „jeńca”, „Prusaka”, będąc zresztą przy tym popychana i szturchana. Być może dzieci narzuciły jej tę rolę, wiedząc o jej pochodzeniu.

Dziewczynka w końcu w niemieckim hełmie trafia z płaczem do matki. Ta zdejmuje fatalny rekwizyt, a Angéle wkrótce wrzuca hełm do ognia i z satysfakcją patrzy, jak płonie.

Pomimo takich scen, jak wskazane powyżej, pierwsze Oskarżam

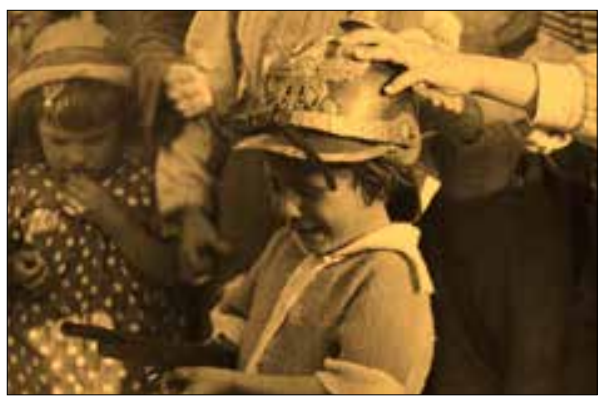

Il. 15. Kadr z filmu Oskarżam (1919). Alzacja i Lotaryngia na mapie Marii Lazare’a

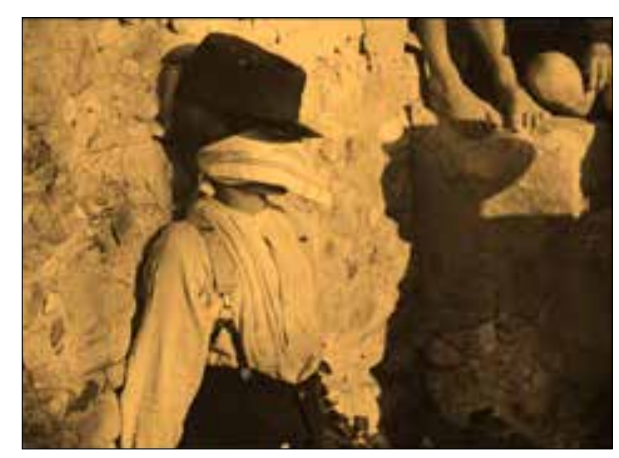

Il. 16. Kadr z filmu Oskarżam (1919). 1918 - Zabawa w wojnę

Il. 17. Kadr z filmu Oskarzam (1919). „Mała Prusaczka" - 3-letnia Angéle jako kozioł ofiarny zabawy w wojnę nie osiąga wymiaru nieskażonego perspektywą narodową uniwersalnie pacyfistycznego przesłania. Gance, afirmując ustami filmowego poety-proroka figurę alegorycznego Gala i unaoczniając, choćby tylko metonimicznie, zbiorowy gwałt niemieckich żołnierzy na Francuzce, pozostał do 
końca patriotą francuskim. Jak ujął to monografista Gance’a: „Paradoks Oskarżam polega na fakcie, iż choć poprzez pokazywanie grozy wojny wołał ów film o pokój, to jednocześnie przypominał narodowi, iż pokój nie mógł być osiągnęty, póki Niemcy nie zostały pokonane, gdyż poprzez atak na Francję i jej wartości stworzyły zagrożenie dla całej cywilizacji”[22]. I to dlatego narracja filmu wydaje się aprobować słowa wypowiedziane przez François do Édith, gdy pod koniec części II wyruszają z Jeanem na front: „To konieczne, byśmy skończyli tę wojnę, bądź dzielna!”.

Gdy w finale Wielkiego Wieczoru ręka małej Angéle prowadziła Jeanowi dłoń z kredą, napis dopowiada: „Dziecko znów nauczyło pisać poetę słowo swego życia”. I jest to "słowo życia” nie tylko Jeana Diaza, ale i samego reżysera, jeśli uwzględnimy tematyczną obsesję Gance’a na przestrzeni czterdziestu lat jego twórczości. A gdy uwzględnić rozmaite funkcje i role, jakie pełnią porte paroles artysty w kolejnych filmach, to w pierwszym Oskarżam jest to rola starotestamentowego proroka, wygłaszającego niczym Jeremiasz tyrady przeciwko pełnemu zła światu, w kolejnych zaś dominują funkcje mesjańska i prometejska, transcendentnego i świeckiego zbawienia świata. W filmie Koniec świata są one rozdzielone na dwóch braci Novalic, Jeana i Martiala. Jean Novalic to poeta i aktor - tuż przed swym ostatecznym popadnięciem w szaleństwo głosi konieczność naprawy moralnej świata, „gdyż czas jest już bliski”. Mesjańskość Jeana ujawnia się już w prologu filmu, którym widzimy go w roli ukrzyżowanego Chrystusa $\mathrm{w}$ wystawionym w kościele pasyjnym misterium wielkanocnym. A Jeana-Chrystusa gra nie kto inny jak Abel Gance. Brat poety-aktora, Martial, jest naukowcem, jednocześnie astronomem, fizykiem i chemikiem. Odkrywa on lecącą ku Ziemi kometę, toteż jego memento mori dla szykującej się do kolejnej wojny ludzkości przybiera postać komunikatu o nieuchronnej fizycznej zagładzie planety. Spektakularność i apokaliptyczność zagrożenia rodzi w ludziach na całym świecie skrajne reakcje - jedni przyjmują postawy pokutne i skłaniają się ku mistycyzmowi, inni, chyba liczniejsi, popadają w orgiastyczne folgowanie wszelkim żądzom i zachciankom, póki jeszcze świat trwa. Giełdy ogarnia szaleństwo, tłumy w panice uciekają nie wiadomo dokąd, płoną miasta, niszczone przez odpryski komety, wzbierają oceany. Ale Martial swymi działaniami wobec nadchodzącej katastrofy powstrzymuje wyścig zbrojeń, udaremnia wybuch wojny i skłania część ludzkości do zjednoczenia wobec wspólnego zagrożenia. Gdy ostatecznie okazuje się, iż choć kometa przeleciała blisko Ziemi i dokonała na niej ogromnych spustoszeń, ale jednak definitywnie jej nie zniszczyła, z inicjatywy Martiala na pełnej zgliszcz i ruin planecie powstają Stany Zjednoczone Ludzkości. Moralna i polityczna, duchowa i świecka zarazem, odnowa ludzkości, to zadanie rozpisane zostało na postacie dwóch braci, z których każdy, w innym aspekcie, jest niewątpliwym alter ego reżysera.

[22] L. Véray, op.cit., s. 41. Zapewne też przez ten paradoks w Niemczech film został uznany za antyniemiecki i szybko zdjęty z niemieckich ekranów. 
Mesjanizm i prometeizm, rozdzielone na braci Novalic, zjednoczą się ze sobą w postaci Jeana Diaza, bohatera drugiego Oskarżam z roku 1937. Nie przypadkiem rolę tę gra Victor Francen, odtwórca roli Martiala w Końcu świata, co czyni z niego poniekąd kontynuację tamtej postaci. Zresztą w kontekście całego filmu, mimo swego imienia i nazwiska, Jean Diaz A.D. 1937 istotnie jawi się raczej jako nowy Martial Novalic niż ponowny awatar Jeana Diaza z pierwszego Oskarżam. A mimo tego samego tytułu drugie Oskarżam nie jest w żadnym wypadku remakiem pierwszego. Jest też w odmiennym kontekście estetycznym (zanik impresjonizmu filmowego, który już kilka lat wcześniej wyczerpał możliwości swej stylistyki; nieprzystawalność trybu alegorycznego kina niemego wobec dominującego w kinie dźwiękowym kreowania znaczeń przez słowo) i produkcyjnym (dużo bardziej podrzędna pozycja reżysera przy znacznie wyższych kosztach realizacji filmu dźwiękowego), filmem artystycznie znacznie mniej udanym. Trzeba jednak przyznać, iż niezmącony koniecznością patriotycznej deklaratywności wobec dramatów ofiar i weteranów tuż zakończonej wojny, i mniej przysłonięty fabularnymi perypetiami miłosnego trójkąta (choć nie do końca wyeliminowanymi), uniwersalny pacyfizm drugiego Oskarżam wybrzmiewa znacznie czyściej.

O ile film z roku 1919 rozpoczynał się w przededniu wojny, a finał miał tuż po jej zakończeniu, obejmując akcją lata 1914-1918, to ów „nie-remake” o tym samym tytule rozpoczyna się tuż przed zawieszeniem broni, w listopadzie 1918 roku, a zasadnicza część akcji dzieje się około 18-19 lat później, współcześnie do realizacji filmu (ukończony w roku 1937, premierę miał w styczniu 1938). W Chattancourt nieopodal Verdun, gdzie wciąż trwają zaciekłe walki i nieustanny wzajemny ostrzał artylerii, stacjonuje kompania Jeana Diaza i François Laurina.

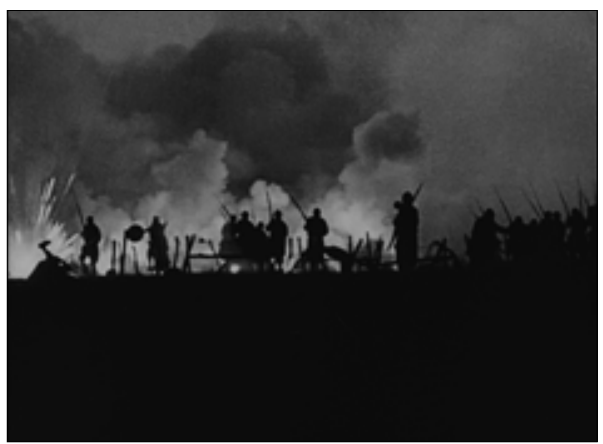

Il. 18. Kadr z filmu Oskarżam (1937). Piekło ostatnich walk

Żołnierze z niepokojem oczekują, czy nie zostaną wyznaczeni do patrolu zwiadowczego - poza Diazem, któremu kiedyś udało się wrócić żywym, nikt nigdy z patrolu nie powrócił. Mimo przekonującego świadectwa Jeana, iż zwiad nie ma sensu, oficer łącznikowy Henri Chimay nie ryzykuje niewykonania nieprzemyślanego rozkazu dowództwa i wylosowana dwunastka (jest w niej François) wyrusza po niemal pewną śmierć. Dołącza do niej Diaz, zastępując na ochotnika ojca czworga dzieci. Wkrótce capstrzyk obwieszcza zawieszenie broni i koniec wojny.

Słyszy go z radością jeden z żołnierzy patrolu, Gilles Tenant. Ranny, nie może jednak wydostać się z błotnistego leja. Bezskutecznie wołając o pomoc, znajduje w końcu śmierć w błocie. Jego ciało nigdy nie zostanie odnalezione, śmierć nie będzie potwierdzona,

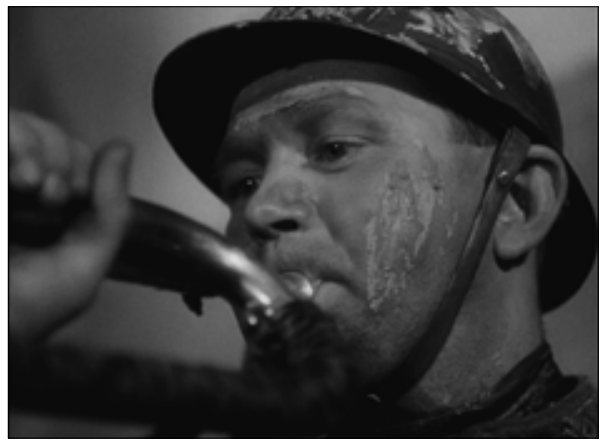

Il. 19. Kadr z filmu Oskarżam (1937). Capstrzyk na zawieszenie broni i koniec działań wojennych 


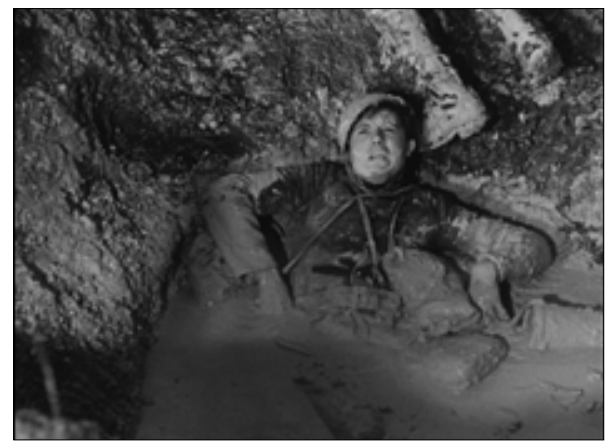

Il. 2o. Kadr z filmu Oskarżam (1937). Gilles Tenant w błotnistej pułapce

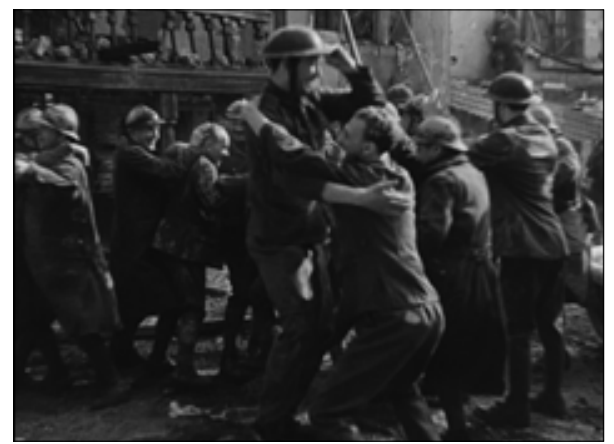

a kochająca go okopowa piosenkarka Flo, czekając na niego, nigdy nie opuści okolic Verdun.

$\mathrm{Na}$ tle wiwatów i radosnych śpiewów żołnierzy dobiegających z rynku miasteczka i z kantyny nieopodal, odbywa się pogrzeb uczestników patrolu, ostatnich, bezsensownych ofiar wojny.

Przygnębienie i rozpacz ich dowódcy i kolegów z oddziału ustępuje radości, gdy okazuje się, iż Diaz jednak przeżył - dzięki jękom wydawanym przez rannego Jeana wydobywają go spod całunu tuż przed pochówkiem. Jean zmartwychwstaje po raz drugi.

Ta pierwsza sekwencja końca wojny, zajmująca około 33 minuty trwającej 116 minut całości, jest najlepsza artystycznie i najmocniejsza w całym filmie. Zaczyna się od obrazu ukrzyżowanego Chrystusa do góry nogami - zbombardowany krzyż zwalił się na miejską fontannę, przez co jej misa przypomina raczej sprofanowaną chrzcielnicę.

Żołnierze zmywają w niej z rąk błoto okopów, opłukują w niej skrwawione bagnety, a jeden desperat, mimo ostrzeżenia o niezdatności do spożycia, pije $\mathrm{z}$ niej wodę.

W kadzi fontanny-chrzcielnicy utonął biały gołąb - żołnierze zaciekle kłócą się o prawo do jego własności, a tym samym do spożycia go. Ucina sprawę Jean, zabierając ptaka i sprawiając mu pochówek. Na

Il. 21. Kadr z filmu Oskarżam (1937). Radość z zakończenia wojny

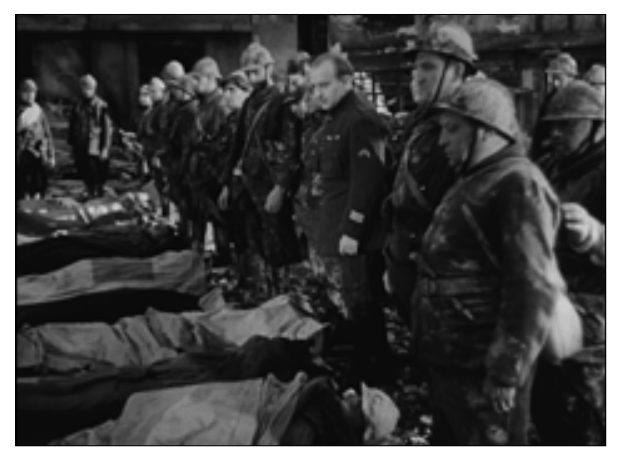

pytanie François, który szuka swego rywala, słyszy on odpowiedź, iż Jean „grzebie gołąbka pokoju”[23].

Flo, okopowa artystka, śpiewa żołnierzom piosenkę Une femme (no bo tego właśnie im trzeba), a frywolny tekst i radosny refren kontrapunktują obrazy strzelających dział i odgłosy rozrywanych pocisków oraz przerywanie występu, gdy Flo i jej rozpaleni słuchacze kulą się przed odłamkami i odpryskami osuwających się ścian. Ta sama piosenka rozbrzmiewać będzie w oddali podczas pogrzebu uczestników patrolu.

Najbardziej jednak szokuje śmierć nieszczęsnego Gillesa Tenanta, który mógłby przeżyć, gdyby ktoś wyciągnął go z feralnego leja, w którego błoto

Il. 22. Kadr z filmu Oskarżam (1937). Powrót ostatniego patrolu coraz bardziej się zapadał. Obraz jego pogrążonego w mazi ciała narracja przywołuje raz jeszcze w niebywałej sekwencji montażowej zestawiającej defiladę zwycięstwa pod Łukiem Triumfalnym z obrazami
[23] Zatem wbrew temu, co się powszechnie sądzi, to nie Picasso wymyślił „gołąbka pokoju” na komunistycznym wrocławskim Kongresie Pokoju w roku 1948, skoro film powstał 11 lat wcześniej. Gance odwołuje się do starodawnej biblijnej symboliki gołębia jako znaku przymierza między narodami - choć raczej ironicznie, skoro ptak jest martwy, skrwawiony i utopiony, pod figurą zwisającego głową w dół odwróconego Chrystusa. 
poległych na polach bitew Wielkiej Wojny. Gance zuchwale przeplata materiały kronikalne ze scenkami inscenizowanymi (jak np. śmierć Tenanta), dając za podkład refren Marsylianki: Aux armes, citoyens,/ Formez vos bataillons!/ Marchons! Marchons!/ Qu'un sang impur/ Abreuve nos sillons („Do broni, bracia dziś!/ Zewrzyjcie szyki wraz!/ I marsz, i marsz!/ By ziemię krwią/ napoić, przyszedł czas!”[24]). Użycie w taki sposób francuskiego hymnu, iż porywający patos muzyki i śpiewu zostaje obezwładniony niemal dosłowną ilustracją treści (a okazuje się ona potworna), rodzi efekt głęboko gorzkiej ironii, dystansującej od wszelkiego patriotyzmu, co mocno odróżnia J’accuse A.D. 1937 od filmu z roku 1919.

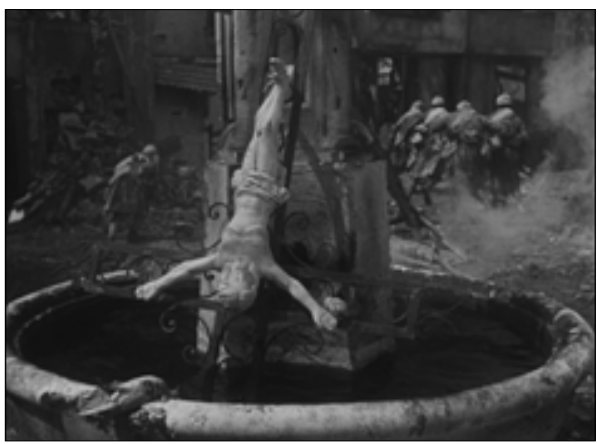

Il. 23. Kadr z filmu Oskarżam (1937). Świat na opak Ale tym samym pacyfizm przesłania tej pierwszej sekwencji filmu wydaje się niczym już niezakłócony. Współgra on zresztą znakomicie $\mathrm{z}$ następującą po czołówce dedykacją: „Dedykuję ten film wszystkim poległym w wojnie jutra, którzy niewątpliwie oglądać go będą ze sceptycyzmem, bez rozpoznania, że to obraz ich samych. Abel Gance”. A także z czołówką filmu, której napisy i nazwiska realizatorów wydają się umieszczone na ogromnym cokole Ossuarium Douaumont - monumentu wzniesionego na znajdującym się nieopodal Verdun największym cmentarzu żołnierzy obu stron konfliktu poległych w tej niekończącej się najdłuższej bitwie I wojny światowej.

Niestety, potężne wrażenie, jakie wywołuje sekwencja końca wojny, zostaje osłabione przez powojenne perypetie fabularne. Jean,

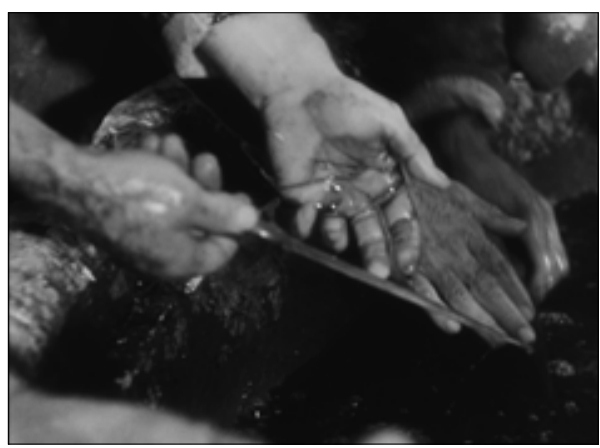

Il. 24. Kadr z filmu Oskarżam (1937). Umywanie rąk i bagnetów wróciwszy do rodzinnego miasta, odtrąca miłość Édith Laurin, pomny na przyrzeczenie dane poległemu François, iż nie skorzysta z jego śmierci, by zająć jego miejsce u boku jego żony. Dzięki protekcji i finansom właściciela przy hucie w St-Paul-de-Vence tworzy laboratorium, w którym pracuje nad „niezniszczalnym” szklanym pancerzem, mającym chronić żołnierzy ewentualnej wojny. Ale chcąc być niezależnym, wynosi się z rodzinnej Prowansji i ,atelier”, w którym kontynuuje prace dla huty, przenosi pod Verdun (jest w nim niewielki piec do wypalania szkła, a w skromnym mieszkanku obok poczesne miejsce zajmuje krzyż ułożony z fotografii jego poległych towarzyszy broni). Nad ich grobami przysięga im, iż uczyni wszystko, by nie dopuścić do wybuchu kolejnej wojny. Po szesnastu latach Jean przyjeżdża do St-Paul-de Vence, gdzie po śmierci dotychczasowego właściciela zarząd huty obejmuje jego spadkobierca, Henri Chimay, przez Jeana obwiniany w duszy za śmierć

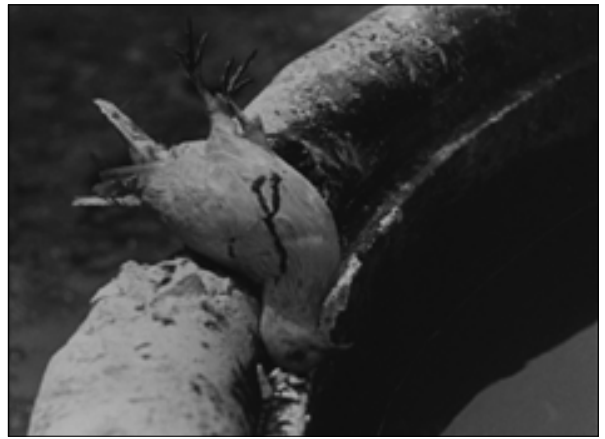

Il. 25. Kadr z filmu Oskarżam (1937). Gołąbek pokoju 


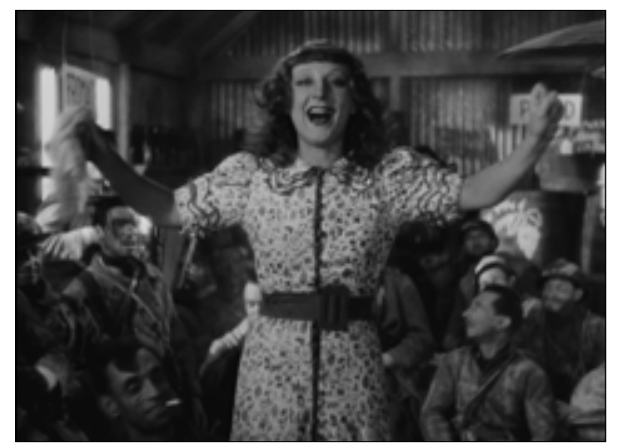

Il. 26. Kadr z filmu Oskarżam (1937). Une femme - okopowy przebój w wykonaniu Flo kolegów. Chimay chce kontynuować współpracę nad „szklanym pancerzem”, ale Diaz jej odmawia, widząc promilitarne zapędy nowego właściciela i zbijanie na zbrojeniach kapitału politycznego. W rozmowie z Chimayem i jego zwolennikami po wiecu, na który ostentacyjnie nie przyszedł, Diaz zaczyna oskarżać. „Kogo pan oskarża,? Tych, którzy wygrali wojnę?” pyta polityk-przemysłowiec. Jean odpowiada tyradą:

Nie, nie oskarżam tych, którzy wygrali wojnę. Oskarżam wczorajszą wojnę, iż stworzyła dzisiejszą Europę. I oskarżam wojnę jutra, iż przygotowuje Europy zniszczenie. Oskarżam ludzkość, iż nie wyciągnęła lekcji z ostatniego kataklizmu i czeka ze złożonymi rękami na następną wojnę. Oskarżam beztroskich, krótkowzrocznych, egoistów, iż pozwolili Europie się podzielić, zamiast budować trwałe przymierze. I oskarżam ludzi dnia dzisiejszego, iż nie tylko nie rozumieją, ale i szydzą, gdy przypomnieć im najpiękniejsze słowa na tej ziemi: miłujcie się nawzajem. I oskarżam tych samych ludzi o ignorowanie milionów głosów poległych w wojnie, którzy wołają do nas już od 20 lat: Stop! Idziecie tą samą straszną ścieżką.

Chimay oponuje, mówiąc, iż nie idą tą samą ścieżką, a idea nowej wojny ich przeraża. „By przeżyć, trzeba walczyć i zwyciężyć” - mówi przemysłowiec. Jean się sprzeciwia: „Nie! By żyć, trzeba kochać!”. Stronnik polityka woła: „Ale nie zmienia to faktu, iż Francji trzeba przywódcy!”. Tonem proroka Diaz odpowiada: „Ale światu trzeba szukać serca”. Tyrada Jeana jest oczywistą apoteozą chrześcijaństwa i odpowiedzią na odejście od jego wartości, którego emblematem była otwierająca film figura odwróconego głową w dół Chrystusa, a alegorycznym wyrazem biały gołąb utopiony w wodzie skażonej i skrwawionej żołnierskimi bagnetami. Pointa tej tyrady niepokojąco jednak też przypomina słowa Marii-kaznodziejki z Metropolis (1926) Fritza Langa, iż „pośrednikiem między rękoma a mózgiem musi być serce”: to pseudochrześcijańskie przesłanie nawoływało w gruncie rzeczy do biernego niesprzeciwiania się złu nawet w kontekście skrajnie niesprawiedliwego systemu ekonomicznego i represyjnego porządku w systemie totalitarnym, co postawą chrześcijańską zgoła nie jest. Radykalny pacyfizm nie jest bowiem receptą na pokój, gdy totalitarne państwa, jak Trzecia Rzesza, stalinowski Związek Sowiecki, Włochy Mussoliniego czy Japonia generałów wprowadzają represyjne prawa, na potęgę się remilitaryzują i niedwuznacznie grożą państwom ościennym. A przecież w takim właśnie kontekście politycznym miała miejsce premiera filmu w styczniu 1938 roku - nie dziwne więc, iż mimo bardzo silnych tendencji pacyfistycznych w ówczesnej Francji i licznych pacyfistyczno-kombatanckich organizacji, jak chociażby współpracujący przy realizacji filmu „ludzie bez twarzy” pułkownika Picota, apel Jeana Diaza (czytaj: Abla Gance’a) pozostał A.D. 1938 wołaniem na puszczy.

Komplikacje zachodzą też w wątkach osobistych. Trójkąt w innej konfiguracji odżywa, gdy Hélène, dorosła już córka Édith i François, 
wyznaje matce, iż kocha Jeana Diaza. Ten ostatni wciąż tak naprawdę kocha Édith, ale pomny swej obietnicy zachowuje nieodmienny dystans; jednak wobec niemożności związania się z ukochaną, nie stroni od uczucia Hélène i nie odtrąca jej jednoznacznie, prawdopodobnie przez uczucie do córki zapośredniczając i kompensując sobie pożądanie matki. Jest w tej relacji, choćby $\mathrm{z}$ racji różnicy wieku i faktu, iż to córka Édith, coś „edypalnego”, wręcz kazirodczego, a sam ten wątek wydaje się w pacyfistycznym dziele niesmaczny i nie na miejscu[25]. Ostatecznie jednak to Henri Chimay, zamożny i stateczny, okaże się wybrankiem Hélène, dopełniając swą osobą do czworokąta geometryczną figurę miłosną.

Jean tymczasem stopniowo przeobraża się w proroka, a poniekąd także w figurę mesjańską. Spotkawszy koło Verdun piosenkarkę Flo, rozpamiętującą nie tylko Gillesa Tenanta, ale i wszystkich poległych żołnierzy, których bawiła na froncie, uświadamia sobie, że musi być, jak i ona, strażnikiem pamięci, ale też i kimś więcej: kimś, kto jakąś transcendentną mocą, prowadzony przez duchy zmarłych, zapobieże kolejnej wojnie. W burzliwą noc, która dla niego jest jakąś „nocą ciemną" w aspekcie mistycznym, nocą próby i przesilenia duchowego, ponosi jednak porażkę. Po powrocie do St-Paul-de-Vence jest przez Édith, Hélène i Henriego Chimay traktowany jak szaleniec i oddany pod kuratelę psychiatry. Prorocki atak gniewu ogarnia go, gdy odkrywa, iż Chimay wdrożył do produkcji opracowany przez niego „szklany pancerz", otrzymał za to państwową nagrodę i zarobił na tym wielkie pieniądze. A komunikaty radiowe i krzykliwe nagłówki gazet powiadamiają o powszechnej mobilizacji w różnych krajach i nieuchronnej już wojnie (sekwencja „przedwojennej gorączki” wykorzystuje przy użyciu błyskotliwego montażu materiały kronikalne z epoki). Diaz wraca do Verdun, a ściślej - do Douaumont, by pod Ossuarium Wielkiej Wojny dokonać w apokaliptyczną noc swego wielkiego dzieła. O ile pochód zmarłych w pierwszym Oskarżam był wydarzeniem niesamowitym, ale jednak tylko lokalnym, dotykającym w Wielki Wieczór jedynie społeczność prowansalskiego miasteczka, to to, czego dokonuje Jean Diaz w drugim filmie, w swą Wielką Noc Ciemną, ogarnia już cały świat i ma iście apokaliptyczny wymiar. Gwałtowna burza nad cmentarzem wojennym w Douaumont-Verdun wydaje się ogarniać cały świat, ptaki i leśne zwierzęta uciekają gdzieś w popłochu, więdną kwiaty... Wszystko to ma posmak czegoś olbrzymiego, wszechświatowego i eschatologicznego jak sąd ostateczny. Jean wzywa najpierw, by powstali z martwych polegli koledzy z jego oddziału, później zaś woła w trzech językach, po francusku, angielsku i niemiecku, wszystkich żołnierzy poległych w nieskończenie długich zmaganiach pod Verdun, których szczątki spoczęły na olbrzymim cmentarzysku Douaumont. Zmarli,

[25] Nie pierwszy raz takie skandaliczne pożądanie pojawia się w twórczości Gance’a - trzeba tu przypomnieć fatalną miłość maszynisty Sisifa i jego syna do ich przybranej córki/siostry w Kole udręki (1922). Zwraca też na to uwagę L. Véray, op.cit., s. 81-82. 


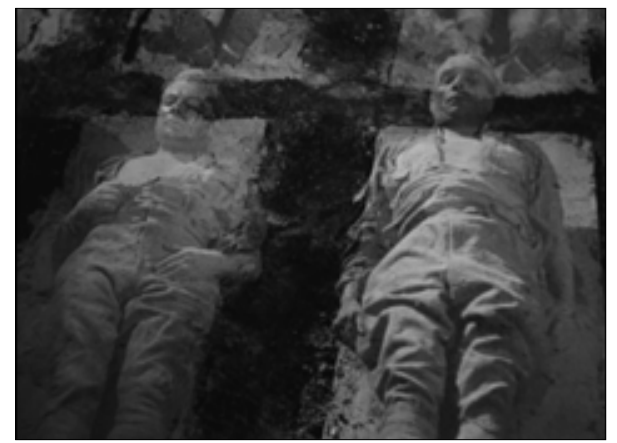

Il. 27. Kadr z filmu Oskarżam (1937). Zmartwychpowstawanie

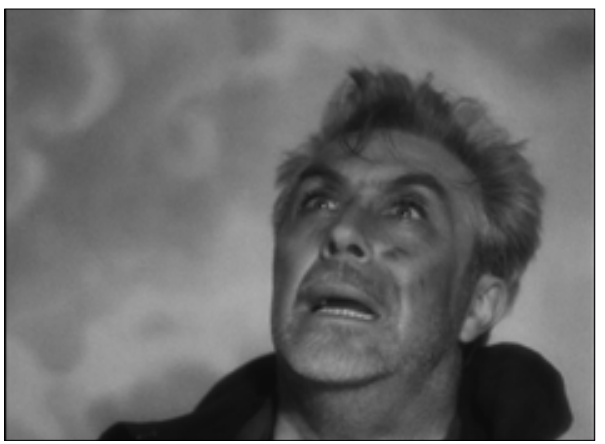

Il. 28. Kadr z filmu Oskarżam (1937). Jean Diaz wzywa poległych

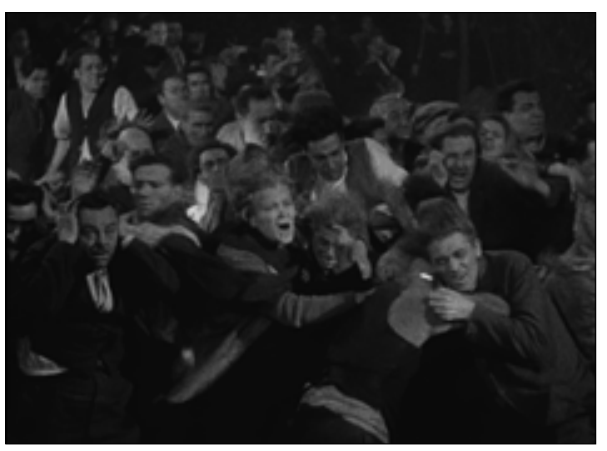

Il. 29. Kadr z filmu Oskarżam (1937). Ludzkość $\mathrm{w}$ panice posłuszni wezwaniu, powstają z grobów, przyoblekają na powrót w ciała szkielety i, ukazani w wielokrotnych ekspozycjach, idą naprzód ku widzowi.

Później Jean wzywa poległych na frontach Wielkiej Wojny żołnierzy wszystkich formacji - marynarzy, lotników, piechurów, artylerzystów, kawalerzystów.

Na świecie wybucha panika: ludność ucieka w popłochu przed pochodami zmartwychwstańców, przerażona tym bardziej, iż na czele marszów znajdują się „ludzie bez twarzy”. Sekwencje apokaliptycznej paniki Gance stworzył, wplatając w materiały kronikalne i nowo nakręcone obszerny materiał filmowy ze swego katastroficznego filmu Koniec świata (1931) - i kto wie, czy owe fragmenty nie wypadły tu lepiej i mocniej niż w pierwowzorze.

Panika ogarnia też armie: mobilizacja przed nadchodzącą wojną okazuje się ostatecznie totalną demobilizacją i rozsypką wszystkich możliwych wojsk, których żołnierze uciekają w takim samym popłochu jak cywile. Jean Diaz osiąga swój obiecany poległym towarzyszom broni cel: udaremnia wybuch nadchodzącej wojny. Pouczona w tak widowiskowy sposób przez ingerencję sił transcendentnych ludzkość powołuje Stany Zjednoczone Ludzkości, na których inauguracyjnym zgromadzeniu płomienne przemówienie o konieczności powszechnego rozbrojenia wygłasza nie kto inny, jak... Henri Chimay:

Są momenty w historii ludzkości, kiedy szok, głęboki wstrząs, który przenika społeczeństwo do samych trzewi, nakłania natychmiast i od razu do przemiany wszelkich stosunków. Taki moment nadszedł. Zmarli polegli w naszych miastach, na naszych polach, są wszędzie wokół nas, w nas samych, czekając, aż żywi zaczną działać tak, jak my właśnie działamy. Zakaz wojny, wszystkich wojen. Rozkazem Powszechnych Stanów Generalnych wojna jest formalnie zniesiona. Powszechne rozbrojenie zostało jednogłośnie przyjęte. Wojna jest już martwa. A świat doznał odnowy.

To zgromadzenie i te deklaracje to niewątpliwy triumf Jeana Diaza, ale czy fakt, iż wygłasza je dotychczasowy producent uzbrojenia, jest też aby triumfem szalonego proroka, czy może gorzką ironią? W samym finale odwróceni od nas polegli wracają do Ossuarium Douaumont, by po zakończeniu swej misji przestrogi dla żywych ponownie spocząć w grobach. Poruszeni świadkowie tego odwrotu przyklękają w nabożnej czci.

Mimo porażających skalą scen masowych, rewelacyjnego montażu, sugestywnych obrazów, film nie jest ani merytorycznym, ani artystycznym sukcesem Abla Gance’a. O ile zapada w pamięć pierw- 
sze pół godziny, gdzie pacyfistycznemu przesłaniu świetnie służą ukazanie okropności wojny i dramatu bezsensownej, niepotrzebnej śmierci bohaterów tuż przed zawieszeniem broni, oraz wieloznaczne, niedopowiedziane i niepokojące obrazy, to psują wrażenie retoryka płomiennych tyrad Jeana $\mathrm{z}$ jej niedobrym patosem, ryzykowność konceptu „mesjańskiej mocy” Jeana Diaza (nie do pogodzenia z chrześcijaństwem, które skądinąd wydaje się dla Gance’a aksjologiczną podstawą) i nieprzystawalność chrześcijańskiej symboliki i ikonografii do świecko-lewicowej wizji zjednoczonej ludzkości jutra niczym z jakiejś sowieckiej utopii. Wielki wizjoner wypuścił więc w roku 1938 dzieło nie tylko „nie na czasie”, ale i skażone nierozwiązywalnymi sprzecznościami ideowymi, które nikogo swą apokaliptyczną metafizyką nie zdołało do pacyfizmu przekonać.

Drugie Oskarżam posłużyło jednak jako podstawa do wielkiego artystyczno-technicznego eksperymentu, jakim jest J'accuse 1956. Gance nie nakręcił nowego filmu - dzieło z roku 1937 zostało mocno skrócone, przemontowane i przystosowane do szczególnego systemu projekcji z użyciem trzech równoległych projektorów, rzutujących obraz na olbrzymi ekran o proporcjach trzech horyzontalnie ustawionych koło siebie ekranów o tradycyjnym formacie 4:3, co w efekcie tworzyło jeden wielki superpanoramiczny obraz o proporcjach mniej więcej 4:1. Gance, już w 1927 roku, realizując Napoleona, myślał o kinie, które superpanoramicznym formatem ekranu wciągałoby sensorycznie widza w świat przedstawiony niczym popularne na przełomie XIX i XX wieku malarskie panoramy, dlatego też niektóre sekwencje swego arcydzieła z 1927 roku, przeznaczone do „tryptykowego” finału, realizował $\mathrm{z}$ trzech horyzontalnie ustawionych kamer. Oczywiście seanse Napoleona wymagały szczególnych obiektów z ogromnym ekranem, gdzie można by film pokazywać. W roku 1927 odbyły się one tylko w ośmiu europejskich miastach i zostały dość szybko zarzucone, gdyż producentów, dystrybutorów, kiniarzy i publiczność bardziej interesowała inna „sensacja dnia” - filmy „mówione” (talkies). Gance ponownie postanowił przystąpić do eksperymentów z rozszerzonym formatem ekranu, reaktywując drugą wersję Oskarżam. W opracowaniu systemu projekcji nazwanego Magirama wielce wspomogła go pochodząca z Argentyny dziennikarka Nelly Kaplan - i to jej nazwisko jako współrealizatora filmu widnieje obok nazwiska Gance’a w czołówce J’accuse 1956. Projekcje filmu miały miejsce w przystosowanym do nich Studio 28 na Montmartre przez około 2 lata, począwszy od grudnia 1956 roku, a po roku 1958 definitywnie ustały. Gance miał nadzieję, iż w dobie wprowadzania w kinie światowym systemów szerokoekranowych projekcji, jak Cinerama czy CinemaScope, jego Magirama może podbić świat. Z tą nadzieją prezentował Oskarżam 3 na festiwalu filmowym, będącym jednym z wydarzeń Powszechnej Światowej Wystawy Expo w Brukseli w kwietniu 1957 roku. Gance próbował lansować swój system, gdyż

Il. 3o. Kadr z filmu Oskarżam (1937). Stany Zjednoczone Ludzkości 


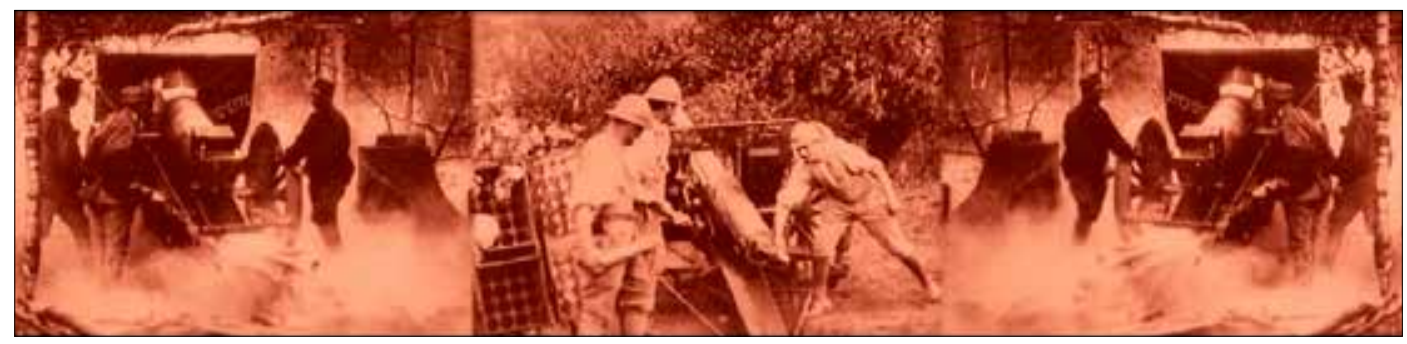

Il. 31. Kadry z filmu Oskarżam (1956). Na froncie Wielkiej Wojny

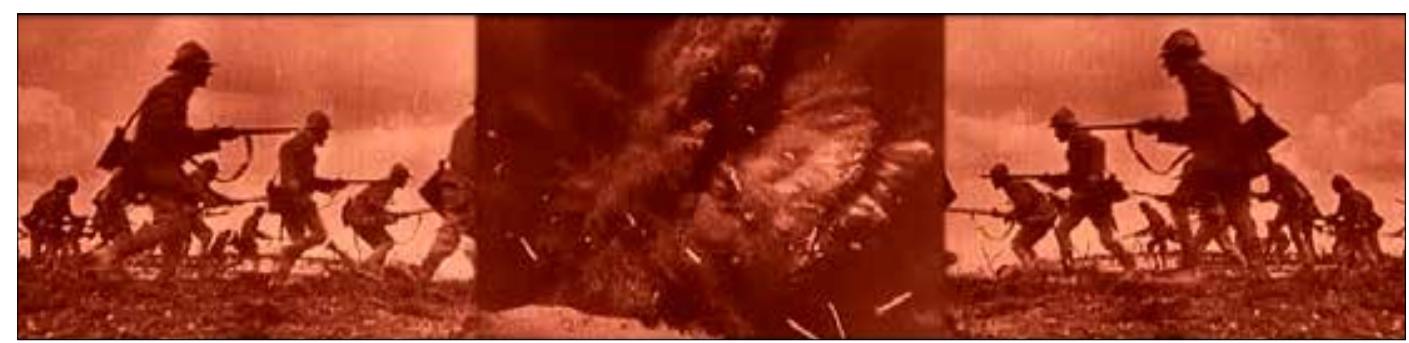

Il. 32. Kadry z filmu Oskarżam (1956). Ostatnie walki 1918 roku

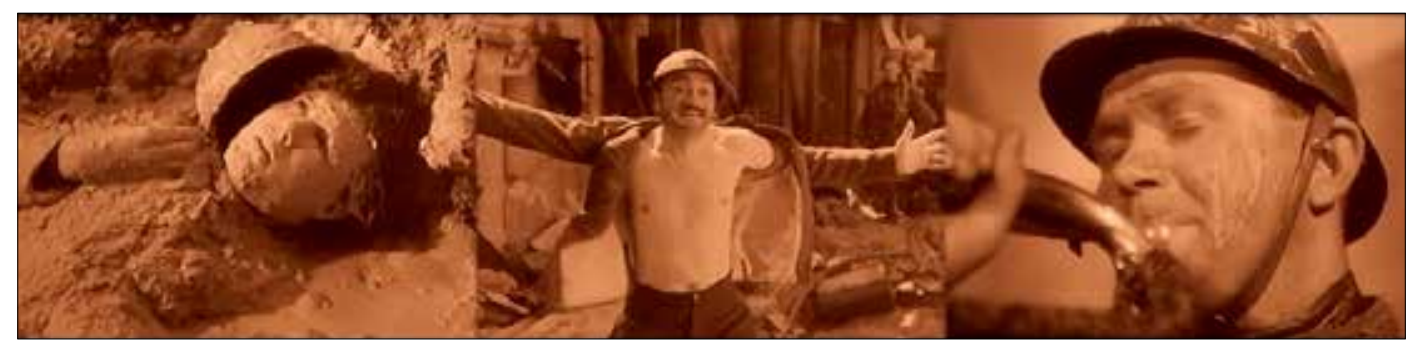

Il. 33. Kadry z filmu Oskarżam (1956). Zawieszenie broni uważał, iż na przykład CinemaScope podobnie ograniczał i twórcę, i widza „stałością" formatu jak format klasyczny - bo to, że proporcja 2,35:1 zastąpi proporcję 4:3, nie stanowiło aż tak wielkiej różnicy. Dla niego liczyła się zmienność formatu, możliwość wyłączania ekranów bocznych, i tym samym przeplatanie w filmie wciągającego widowiska $\mathrm{w}$ superformacie $\mathrm{z}$ fragmentami refleksyjno-kontemplacyjnymi na pojedynczym, środkowym ekranie[26].

Czy wybór tematu pacyfistycznego posłużył tylko jako pretekst dla eksperymentów formalnych i technicznych, czy też wołanie o pokój nadal było jednak dla Gance’a czymś istotnym? Niewątpliwie, po II woj-

[26] Genezę Magiramy i konteksty eksploatacji trzeciego Oskarżam obszernie omawia L. Véray, op.cit., s. $103-115$. 


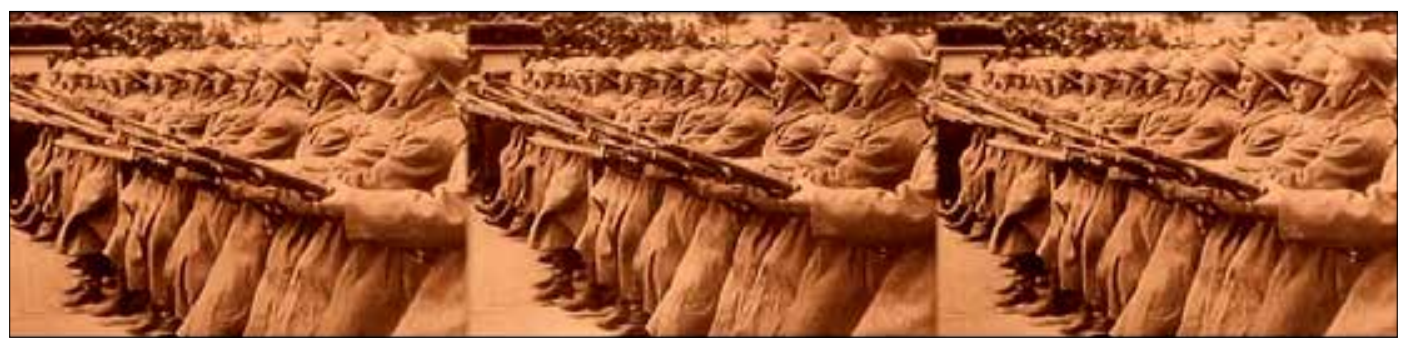

Il. 34. Kadr z filmu Oskarżam (1956). W przededniu nowej wojny

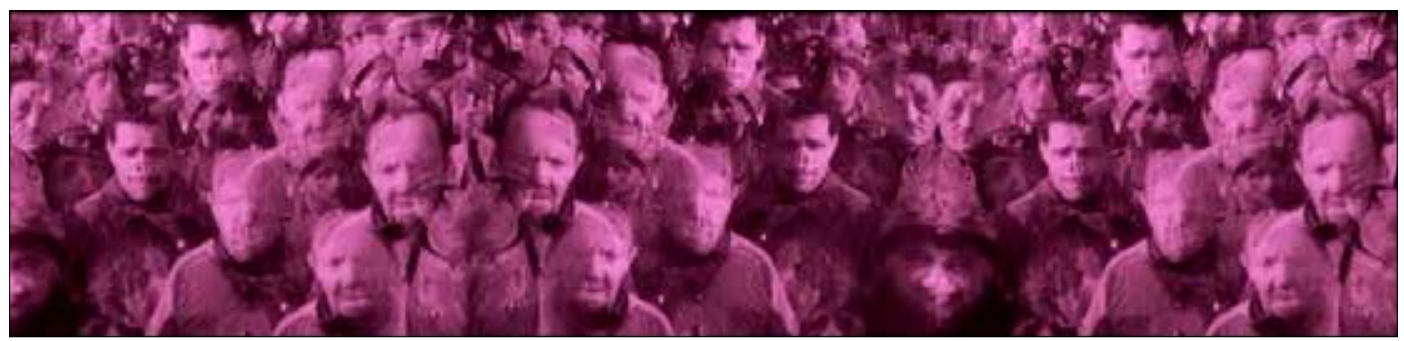

nie światowej, jeszcze straszliwszej niż pierwsza, oraz w dobie zimnej wojny i wyścigu zbrojeń lat pięćdziesiątych, temat ten nadal musiał być dla reżysera priorytetowy. W trzecim filmie, wykorzystującym ten sam materiał co pierwszy, pojawiła się wprawdzie aktualizacja: po około 20-minutowej sekwencji pokazującej ostatnie potyczki I wojny światowej i zawieszenie broni następuje napis: „21 lat później, sierpień 1939”.

Narracja „wycina” obecne w wersji drugiej powojenne perypetie Jeana (praca nad „szklanym pancerzem”, miłosny czworokąt) i od razu przechodzi do Wielkiej Nocy dokonanego mocą Diaza zmartwychwstania poległych i następującej po nim ogólnoświatowej paniki. Ale choć pochody zmarłych wywierają takie wrażenie, to - jak wiemy już ze świata pozafilmowego - we wrześniu 1939 wybuchła kolejna wojna światowa. Toteż w finale trzeciej wersji polegli podczas I wojny światowej powracają do swych grobów na cmentarzu w Douaumont-Verdun, ale powołaniem Stanów Zjednoczonych Ludzkości film już nas nie raczy: rzeczywistość dziesięciolecia między końcem II wojny światowej a powstaniem filmu ewidentnie taką możliwość wykluczyła.

Trzecią odsłonę J'accuse trzeba uznać za znacznie bardziej artystycznie udaną niż druga. Pozbawiona płomiennych, retorycznych tyrad i niepotrzebnych melodramatycznych komplikacji, działa ona niezwykle silnie emocjonalnie i percepcyjnie poprzez nagromadzenie rozmaitych „atrakcji” w rozumieniu Eisensteinowskim (czytaj zatem: „okropności”) na trzech horyzontalnie ustawionych ekranach. Siłę oddziaływania „tryptykowe” sekwencje Oskarżam 1956 mają nie mniejszą niż choćby sławetne schody odeskie z filmu Pancernik Potiomkin, wywołując „litość i trwogę” odbiorcy. Oszołomiony kalejdoskopowymi,
Il. 35. Kadr z filmu Oskarżam (1956). Pochód ludzi bez twarzy 
dynamicznymi i przerażającymi obrazami na trzech ekranach, widz z pewnością mocniej uwewnętrznia pacyfistyczne przesłanie sensorycznie niż na sposób dyskursywny, po patetycznych tyradach Jeana i Henriego Chimay w wersji drugiej. Szkoda tylko, że na podstawie obejrzenia tego filmu z płyty, jego działanie na percepcję i emocje odbiorców podczas projekcji w paryskim Studio 28 lub podczas brukselskiego Expo w roku 1958 można sobie jedynie wyobrażać[27].

B I B L I O G R A F I A

Apollinaire G., Wybór pism, red. A. Ważyk, Warszawa 1980

Brownlow K., The Waste of War: Abel Gance's J'accuse, Los Angeles 2008

Eisenschitz B., Abel Gance, [w:] Cinema: A Critical Dictionary. The Major Filmmakers, red. R. Roud, vol. I. Aldrich to King, London 1980, s. 404-415

Girard René [blok monograficzny], „Literatura na Świecie” 1983, nr 12 (149)

Girard R., Kozioł ofiarny, przeł. M. Goszczyńska, Łódź 1987

Girard R., Prawda powieściowa i kłamstwo romantyczne, przeł. K. Kot, Warszawa 2001

Girard R., Sacrum i przemoc, przeł. M. i J. Plecińscy, Kraków 2019

Irzykowski K., Dziesiąta Muza oraz pomniejsze pisma filmowe, Kraków 1982

Véray L., Abel Gance: Le Visionnaire contrarié / Abel Gance: The Thwarted Visionary, Gaumont, Paris 2017

F I L M O G R A F I A

La Roue (1922), reż. Abel Gance; edycja BluRay: La Roue de Abel Gance. En version intégral restaurée, Pathé, Paris 2021

Napoléon vu par Abel Gance (1927), reż. Abel Gance; edycja BluRay: Napoleon. Abel Gance's Revolutionary Silent Epic, BFI, London 2016

Wszystkie poniżej wymienione filmy na podstawie edycji BluRay/DVD: J’accuse, Gaumont, Paris 2017:

Mères françaises (1916), reż. Louis Mercanton i René Hervil

Les Gaz mortels (1916), reż. Abel Gance

J'accuse (1919), reż. Abel Gance

La Fin du monde (1931), reż. Abel Gance

Jaccuse (1937), reż. Abel Gance

J’accuse (1956), reż. Abel Gance [film w systemie Magirama]

[27] Może by warto zatem zorganizować trzeciej wersji - albo najlepiej wszystkim trzem - takie seanse, jakie miały miejsce po odrestaurowaniu przez Kevina Brownlowa Napoleona. Najsłynniejszy miał miejsce 30 listopada 2016 roku w pękającym w szwach od przybyłej publiczności londyńskim Royal Festival
Hall. Orkiestra filharmoników pod dyrekcją Carla Davisa, który skomponował do filmu muzykę, grała nieprzerwanie 8 godzin podczas projekcji całego, ok. 6-godzinnego filmu i ok. 100-minutowej przerwy na obiad. Film i orkiestra otrzymały od uniesionej publiczności owacje na stojąco. 